\title{
Potential Impact of Microplastics and Additives on the Health Status of Loggerhead Turtles (Caretta caretta) Stranded Along the Central Adriatic Coast
}

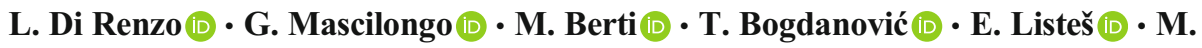

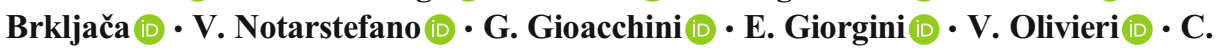 \\ Silvestri • M. Matiddi • N. D'Alterio (iD) - N. Ferri (D) - F. Di Giacinto (D)
}

Received: 28 August 2020 / Accepted: 10 January 2021 /Published online: 26 February 2021

(C) The Author(s) 2021

\begin{abstract}
Loggerhead sea turtle (C. caretta) is the official European bioindicator of marine litter in the Mediterranean Sea. In 2019, 8 sea turtles, out of 28 specimens loggerhead on the Adriatic coast of Molise, were subjected to necropsy. The intestinal contents were collected and the microplastics until $0.45 \mu \mathrm{m}$ were extracted. Qualitative and quantitative assessments were performed by
\end{abstract}

L. Di Renzo and G. Mascilongo contributed equally to this work.

L. Di Renzo $(\bowtie) \cdot$ G. Mascilongo $\cdot$ M. Berti •

N. D'Alterio · N. Ferri · F. Di Giacinto

Istituto Zooprofilattico Sperimentale dell'Abruzzo e del Molise

"G. Caporale" (IZSAM), via Campo Boario snc, 64100 Teramo, Italy

e-mail:1.direnzo@izs.it

T. Bogdanović $\cdot$ E. Listeš

Croatian Veterinary Institute, Poljička cesta 6, 21000 Split, Croatia

M. Brkljača

Faculty of Food Technology and Biotechnology, University of

Zagreb, Pierottijeva 6, 10000 Zagreb, Croatia

V. Notarstefano · G. Gioacchini · E. Giorgini

Department of Life and Environmental Sciences, Università

Politecnica delle Marche, via Brecce Bianche, 60131 Ancona, Italy

V. Olivieri

Centro Studi Cetacei Onlus (CSC), via M. Mantini 15,

65125 Pescara, Italy

C. Silvestri · M. Matiddi

Italian National Institute for Environmental Protection and

Research (ISPRA), via Vitaliano Brancati, 00144 Rome, Italy stereomicroscope observation and spectroscopic analyses (attenuated total reflection-Fourier transform infrared spectroscopy, ATR-FTIR and Raman microspectroscopy, RMS). Moreover, the analytical quantification of polyethylene terephthalate (PET), polycarbonate (PC), para phthalic acid (PTA) and bisphenol A (BPA) in fat and liver tissues was performed by LC-MS/MS. Microparticles ranging from $0.45 \mu \mathrm{m}$ to $1 \mathrm{~mm}$ were found in all turtles, for a total of 623 , while plastic litter greater than $1 \mathrm{~mm}$ were found only in 4 specimens (ranging from 0.03 to $0.11 \mathrm{~g}$ ). Nineteen different polymers and 10 pigments, including polyester (100\% of animals), high-density polyethylene (50\%) and polypropylene $(50 \%)$ were identified. BPA, PTA and PET were detected in fat and liver tissues of all animals, while PC was found only in 50\%. A major prevalence was registered in the abdominal fat tissue, although only PC compounds were significantly higher in abdominal tissue $(p<0.05)$, except for free PTA with liver tissue being the most contaminated $(p<0.05)$. Microplastics and additives surely impact the health status of turtles that showed gastrointestinal impairment and an important level of contamination in tissues.

Keywords C. caretta $\cdot$ Necropsy $\cdot$ Microplastics . Additives · Spectroscopic characterisation - UPLC MS/ MS analyses

\section{Introduction}

The loggerhead turtle, Caretta caretta, is the most widespread sea turtle in the Mediterranean Sea (Casale and 
Turker 2017). Recognised as vulnerable species in the IUCN (International Union for the Conservation of Nature) Red List, this turtle is endangered by numerous anthropogenic threats such as fishing, maritime traffic, chemical pollution and marine debris (IUCN 2015). According to the Marine Strategy Framework Directive (MSFD) and its Descriptor no. 10 for Good Environmental Status (GES), the European Commission recognised $C$. caretta as the official indicator for quantitative and qualitative monitoring of marine litter ingested by marine animals in the Mediterranean basin (MSFD-TSGML 2013). The loggerhead turtle has become the Mediterranean equivalent of the Nordic European indicator, Fulmarus glacialis, already adopted in the North Sea (OSPAR 2018). A pilot study, conducted by Italian researchers, revealed loggerhead sea turtle as the main target species for litter ingestion in the European countries of the Mediterranean Sea, where fulmar is absent (Matiddi et al. 2011; 2017; Camedda et al. 2014). Thanks to the European project INDICIT (https://indicit-europa.eu); this research has been extended also in the Adriatic Sea since 2017.

Loggerhead turtle is a worldwide symbol of awareness campaigns on marine litter contamination. Considering its long life, trophic position and mobility, this turtle can accumulate pollutants along the trophic chain and overlarge areas in different aquatic compartments. Feeding habits bring adults/sub-adults diving at the sea bottom and the along water column, while juveniles feed at the surface, mistaking plastics with food (Thomas et al. 2002; Lazar and Gracan 2011; Digka et al. 2020). Being a generalist species, it probably confuses plastic with preys much more frequently than other turtle carnivores (Plotkin and Amos 1990, Schuyler et al. 2013).

Any solid material dispersed and abandoned in the marine environment (UNEP 2005, 2009) is defined as marine litter. It is mainly composed by plastic debris that are officially classified according to their dimension: macroplastics (>5 mm), microplastics (MP) $(<5 \mathrm{~mm}$; $>0.1 \mu \mathrm{m})$ and nanoplastics $(<0.1 \mu \mathrm{m})$ (NOAA 2009; GESAMP 2015, 2019; Browne et al. 2008). The main polymers discharged in the marine environment are polyethylene (PE), polyethylene terephthalate (PET), polypropylene (PP), polyvinyl chloride (PVC), polystyrene (PS), polycarbonate (PC) and nylon. Some are floating (i.e. PE, PP) and others sinking (i.e. PET, PC, nylon) based on their specific density (Coyle et al. 2020).

The Mediterranean basin is one of the most impacted areas by marine litter and within it the Adriatic Sea even more (Suaria and Aliani 2014; Deudero and Alomar 2015; Fossi et al. 2018). A recent study on this basin calculated floating MPs (127 thousand particles $/ \mathrm{km}^{2}$ ) and seabed micro litter (36 particles/100 g dry weight), showing comparable data with those already published for the Mediterranean Sea (Palatinus et al. 2019). The plastic occurrence in the Adriatic biota reported that $35.2 \%$ of loggerhead sea turtles was affected by plastics (Gomiero et al. 2018). MPs ingestion was also detected in 13 species of fish and 11 species of invertebrates living in the Adriatic Sea by showing a frequency of 25.7\% (Avio et al. 2020). Moreover, the mean number of ingested plastics was ranged between 1.0 and 2 items/ fish for commercial species like European pilchard, spiny dogfish, European hake, red mullet and tub gurnard (Gomiero et al. 2018; Avioet al. 2020). The most common polymers found in the digestive tract of sea turtles and fish are PVC, PE, PP and PET (Gomiero et al. 2018; Avio et al. 2020).

The two major categories of microplastics adverse effects on the organisms include physical effects, due to particle size, shape, and concentration, and chemical effects, related to hazardous chemicals (additives and polymeric raw materials, chemicals absorbed from the environment). Additives as chemicals intentionally added during plastic production improve the performance of plastic products, but many of them are toxic, and their potential for the contamination of the environment as well the biota is high (Campanale et al. 2020). Moreover, in almost all cases, they are not chemically bound to the plastic polymer that contributes to its instability within plastic products, facilitates leaching, and consequently resulting in a high prevalence in aquatic environments, particularly in landfill leachates (Campanale et al. 2012). Bisphenol A (BPA) is a common plasticiser used in industry, especially in polycarbonate (PC) plastics manufacturing processes and food packaging. Para-phthalic acid (PTA) is used as additive or polymer production aid (PPA) as well as monomer of polyethylene terephthalate (PET) (EU Regulation No 10 12011). PTA and BPA were detected in the marine environment and biota (Rudel et al. 2003), in marine fauna, like whale (Fossi et al. 2012), annelids, molluscs (Wang et al. 2019), crustaceans, fish (Oehlmann et al. 2009) and sea turtles (Casini et al. 2018) with possible negative effects on reproduction and hormone functions (Oehlmann et al. 2009; Hong et al. 2018).

Scientific literature is already reporting many studies on plastic ingestion by sea turtles at a worldwide level. 
Data are registered according to the dimensions and chemical composition of plastic fragments in the distinct gastrointestinal tracts where they were recovered. Moreover, several techniques have been exploited to detect MPs from different matrixes (Lenz et al. 2015; Van der Hal and Ariel 2017; Miller et al. 2017; Schymanscki et al. 2018), mostly has been applied on green sea turtles (Cheloniamydas) (Caron et al. 2018a, b). Di Renzo et al. (2020) published preliminary results on a novel extraction protocol of MPs from the gastrointestinal tract of sea turtles stranded in Abruzzo and Molise Regions.

In the Adriatic Sea, qualitative and quantitative data are poor; Lazar and Gracan (2011) investigated the loggerhead stranded/caught dead in the North part of the basin by registering a presence of macroplastic debris $(>1 \mathrm{~cm})$. Further data are necessary to understand the impact of MPs and their additives on loggerhead turtle health in this area. Apart from phthalates detected in tissues (Savoca et al. 2018), no other study was been performed to evaluate the concomitant presence of MPs in the intestinal tract and polymers/plasticisers in tissues of loggerhead turtles stranded along the Adriatic coasts.

The overall objective of this work is to analyse the potential impact of MPs and their additives on loggerhead turtles necropsied in 2019, caught dead or stranded along Adriatic coast of Molise Region. Quantitative and qualitative assessment of MPs until $0.45 \mu \mathrm{m}$ in the intestinal tract of turtles has been evaluated by stereomicroscope observation and characterised by attenuated total reflection-Fourier transform infrared spectroscopy (ATRFTIR) and Raman microspectroscopy (RMS). In addition, for the first time, the analytical quantification of PET, PC, PTA and BPA in fat and liver tissues of sea turtles was performed by LC MS/MS analysis. Data were statistically integrated with the information on the overall status of carcasses, with particular regard to the enteric lesions merged during necropsies, in order to gain new knowledge on the potential impact of MPs on the health of sea turtles causing stranding and death in the Adriatic Sea.

\section{Materials and Methods}

\subsection{Necropsy Sample Collection}

From 2019, all marine turtles stranded or caught dead along the Adriatic coast of Molise Region, are recovered by the official regional network for stranded animals (DCA 16/02/2018 n.12 n.d.). It is composed by Istituto
Zooprofilattico Sperimentale dell'Abruzzo e del Molise "G. Caporale" (IZSAM), Centro Studi Cetacei (Rescue Center), Coast Guard, local veterinarians and municipal offices.

In 2019, a total of 28 loggerhead sea turtles (C. caretta) stranded in Molise coast (3 alive and 25 dead). Based on their conservation status, 8 specimens were necropsied by IZSAM, according to an optimised protocol deriving from already published guidelines (Flint et al. 2009; Poppi and Di Bello 2015). A numerical code, from no. 1 to no. 8 , was assigned to each necropsied turtle (Fig. 1).

Biometric data were measured for each carcass; the curved carapace length (CCL) and weight are reported in the results. The body condition score (BCS) for each one was assigned in accordance with the amount of adipose tissue present at the abdominal level. Observing the gonads, gender and sexual maturity were determined. The intestinal content was sampled and stored in glass containers at $+4{ }^{\circ} \mathrm{C}$. Liver and abdominal fat tissue were collected using aluminium paper and frozen at $-20{ }^{\circ} \mathrm{C}$. Anatomo-pathological lesions were evaluated.

\subsection{Microplastic Extraction Protocol (MEP)}

The extraction protocol of MPs (MEP) from the intestinal content stored at $+4{ }^{\circ} \mathrm{C}$ was arranged into four steps (Di Renzo et al. 2019): (1) litters were washed with tap water throughout metallic mesh of $1 \mathrm{~mm}$; MPs bigger than $>1 \mathrm{~mm}$ were detected according to the INDICIT protocols (Matiddi et al. 2019); scrubbing water (SW) was collected in a glass beaker; (2) $20 \% \mathrm{w} / \mathrm{w}$ of SW containing litter $(<1 \mathrm{~mm})$ washed during the previous step, was collected and left to settle for $24 \mathrm{~h}$; (3) the supernatant part of this settled SW was filtered with a vacuum system using nitrate cellulose filter $(0.45 \mu \mathrm{m}$, Millipore $\left.{ }^{\circledR}\right)$; to clean the filter, $10 \mathrm{ml}$ of hydrogen peroxide solution $\left(30 \% \mathrm{H}_{2} \mathrm{O}_{2}\right.$, chem-LABß) for $5 \mathrm{~min}$ were added on the top of the paper; as soon as the final washing procedure was concluded with $10 \mathrm{ml}$ of milliq water for $5 \mathrm{~min}$, the filter was immediately put in a glass petri dish and (4) the sediment part of the settled SW was dried in a stove at $75^{\circ} \mathrm{C}$ for $2 \mathrm{~h}$; then, the extraction solution, zinc chloride (1.5-1.7 $\mathrm{g} \mathrm{cm}^{-3} \mathrm{ZnCl}_{2}$, Sigma Aldrich $\left.{ }^{\circledR}\right)$, was added and stirred for $12 \mathrm{~h}$; after sonication and a sedimentation period, supernatant was centrifugated at $3000 \mathrm{rpc}$ for $5 \mathrm{~min}$ and filtered using the same procedure applied for aqueous third step. 


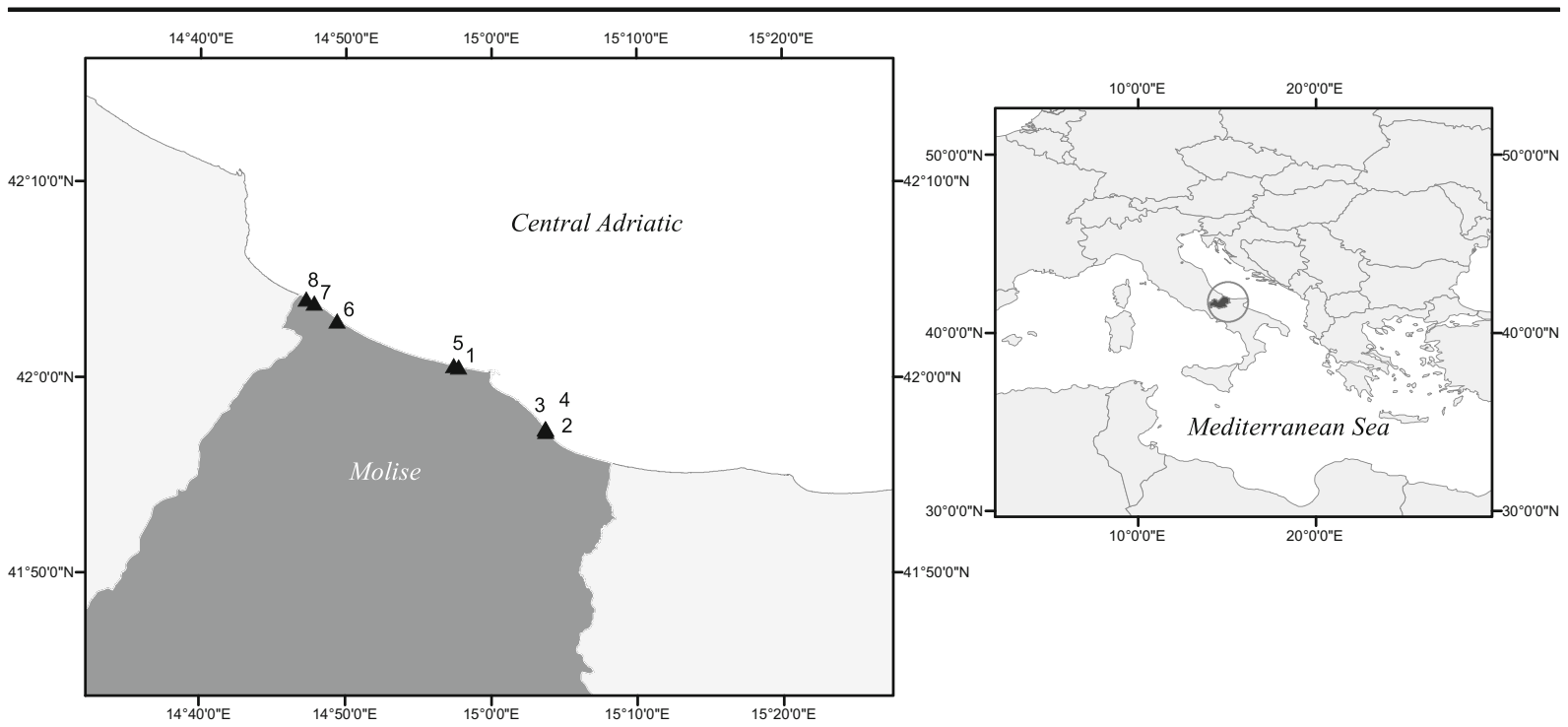

Fig. 1 Map of stranded sea turtles in Molise Region. The stranding locations are numbered with turtle codes

All paper filters were observed under stereomicroscope at $\times 40$ magnification (Leica MZ6) shooting pictures with digital camera (model JVC TKC1381). Each gridded filter has been read from the top down and from left to right, in the opposite direction for each subsequent line until the end. Microparticles that were assumed by eye to be MPs were registered according to number, colour and shape. The last one has been categorised as follows: fragment (rounded, subrounded, subangolar, angular), filament (long-thin fibre), film (irregular membrane) and sphere (spheroid). Potential environmental contamination was evaluated arranging a blank sample for each extraction phase. Chemical identification of extracted microparticles was executed by ATR-FTIR and RMS.

\subsection{Spectroscopic Characterisation: Attenuated Total} Reflection-Fourier Transform Infrared (ATR-FTIR) Spectroscopy and Raman Microspectroscopy (RMS)

The spectroscopic characterisation of microparticles extracted as previously described was performed by ATRFTIR and RMS techniques. In particular, the particles extracted following the first step of MEP (MPs > $1 \mathrm{~mm}$ ) were isolated in a glass Petri dish and were analysed by means of a Bruker INVENIO FTIR Spectrometer equipped with a Platinum ATR (Bruker Optics, Ettlingen, Germany) in the $4000-600 \mathrm{~cm}^{-1}$ spectral range (128 scans, spectral resolution $4 \mathrm{~cm}^{-1}$ ).
Those extracted following steps 3 and 4 of MEP $(\mathrm{MPs}<1 \mathrm{~mm})$ were characterised by a XploRA Nano Microspectrometer (Horiba Scientific) directly on the filters, which were inspected by visible light using a $\times$ 10 objective (Olympus MPLAN10x/0.25); the detected microparticles were measured by RMS using a $\times 100$ objective (Olympus MPLAN100x/0.90) (spectral range 160-2000 $\mathrm{cm}^{-1}, 785 \mathrm{~nm}$ laser diode, 600 lines per $\mathrm{mm}$ grating). Raman spectra were dispersed onto a 16-bit dynamic range Peltier cooled CCD detector; the spectrometer was calibrated to the $520.7 \mathrm{~cm}^{-1}$ line of silicon prior to spectral acquisition.

Both IR and Raman spectra were submitted to polynomial baseline correction and vector normalisation, to reduce noise and enhance the spectrum quality and signal to noise ratio S/N (OPUS 7.5, Bruker Optics). All spectra were then compared with those contained in the spectral library of the KnowItAll software (Bio-Rad Laboratories, Inc.). Similarities of more than 75 of Hit Quality Index (HQI) were considered satisfactory.

\subsection{PET and PC Determination}

\subsubsection{Sample Preparation}

All the liver and fat tissue samples were kept frozen until analysis. The internal standards terephthalic-2,3,5,6-d4 acid (d4-TPA, CAS 60088-54-2) and 2,2-Bis(4hydroxyphenyl)propane-d16 (d16-BPA, CAS 9621087-6) were purchased from Merck KGaA, (Darmstadt, 
Germany). In brief, approximately $0.5 \mathrm{~g}$ of tissue (fortified with $10 \mu \mathrm{g}$ of D4-TPA and $10 \mu \mathrm{g}$ of D16-BPA) were depolymerised via hydrolysis within $30 \mathrm{~min}$ in 1pentanol solution with potassium hydroxide heating at $135^{\circ} \mathrm{C}$ and extracted twice with total of $50 \mathrm{ml} \mathrm{HPLC}$ grade water according to Zhang et al. 2019. One milliliter of extracted sample was diluted with HPLC grade water to $10 \mathrm{~mL}$ and adjusted to $\mathrm{pH} 2-3$ with $\mathrm{HCl}$ before SPE. The cartridges (STRATA-X $6 \mathrm{cc} / 200 \mathrm{mg}$ ) were conditioned by $12 \mathrm{~mL}$ of methanol $(\mathrm{MeOH})$ and equilibrated with $12 \mathrm{~mL}$ of HPLC grade water. Then, the extracts were passed through the cartridge. Cartridges were washed by $5 \mathrm{~mL}$ of HPLC grade water $(0.1 \%$ formic acid) containing $10 \% \mathrm{MeOH}$ before dryness. Finally, the target analytes were eluted with $10 \mathrm{~mL}$ of $\mathrm{MeOH}$. The solvent was evaporated to near dryness under a vacuum of a gentle stream of nitrogen. The sample was reconstituted in a $1 \mathrm{~mL}$ of water $/ \mathrm{MeOH}$ $(8.5: 1.5 \mathrm{v} / \mathrm{v})$, filtered over PVDF 0.22- $\mu \mathrm{m}$ syringe filter and transferred into an auto-sampler vial for UPLC-MS/ MS analysis. Freely available concentrations of PTA and BPA in liver and fat tissue were extracted after the same procedure as above except heating. The concentrations of PET and PC in samples were calculated according to Wang et al. (2017) and Zhang et al. (2019) equations where polymers building block compounds, i.e. para-phthalic acid (PTA) and bisphenol A (BPA) were obtained after subtracting free BPA and free PTA from the depolymerised BPA and PTA.

The calculations of the depolymerised and free BPA (Bisphenol A-BPA, certified reference material, TraceCERT(R), 42,088-100 mg) and depolymerised and free PTA (PTA-paraphthalic acid for synthesis, $8,007,620,100)$ were based on the ten-point calibration curve using the ratio of the standard area (BPA, PTA) to the isotope labelled internal standards (IS) area (y) (Bisphenol A-d16 (BPA-d16, CAS 96210-87-6, 98\% atoms D; terephthalic-D4 acid 97 atom \% D, PTA-d4, 195,553-1G) from Merck KgaA (Darmstadt, Germany) against the analytes concentration $(\mathrm{x})$.

\subsubsection{UPLC MS/MS Analyses}

The analyses of standard solutions and samples were carried out with an Ultra Pressure Liquid Chromatograph (1290 Infinity) equipped with a binary gradient pump (G4220A) and an auto-sampler having a thermostated sample compartment (G4226A), a thermostated column compartment (G1316C) and
1290 Infinity triple quadrupole mass spectrometer G6460C equipped with electrospray ionisation source in positive/negative mode (ESI-MS/MS), both from Agilent (Agilent technologies, Inc., Singapore). The chromatographic separations were performed on Poroshell 120 EC-C18 column $(100 \times 2.1$-mm internal diameter, $2.7-\mu \mathrm{m}$ particle size) and Polaris C18-Ether column $(100 \times 3.0-\mathrm{mm}$ internal diameter, 3.0- $\mathrm{mm}$ particle size) preceded by a Poroshell 120 EC-C18 Guard pre-column (2.1 $\mathrm{mm}$ i.d., 2.7- $\mu \mathrm{m}$ particle size) from Agilent (Santa Clara, CA) for BPA and PTA, respectively. For both BPA and TPA analyses, the injection volume was $15 \mu \mathrm{L}$. The mobile phase was comprised of $\mathrm{MeOH}(\mathrm{A})$ and HPLC grade water $(0.1 \% \mathrm{v} / \mathrm{v}$ ammonium hydroxide solution acid) (B) for BPA and acetonitrile $(0.1 \% \mathrm{v} / \mathrm{v}$ formic acid) (A) and HPLC grade water $(0.1 \% \mathrm{v} / \mathrm{v}$ formic acid) (B) for PTA. The flow rates of 300 and $250 \mu \mathrm{L} / \mathrm{min}$ were applied for BPA and TPA, respectively. The $\mathrm{LC}$ gradient elution programs for BPA and PTA were presented in Supplementary Table Sx 11. The columns were kept in a column oven at $40{ }^{\circ} \mathrm{C}$. The eluent from the column was directly transferred into the ESI interface. The fragmentation pathway study and the optimisation of the mass spectrometry conditions were achieved by direct infusion of a $10 \mu \mathrm{g} / \mathrm{g}$ methanolic standard solutions of each compound (BPA and PTA as the analytes and BPA-d16 and PTA-d4 as the IS) into the ion source with a flow rate of $0.2 \mathrm{ml} / \mathrm{min}$. ESI final conditions were: capillary voltage $3500 \mathrm{~V}$, sheath gas temperature $300{ }^{\circ} \mathrm{C}$, sheath gas flow $12 \mathrm{l} / \mathrm{min}$, nebuliser pressure $40 \mathrm{psi}$, drying gas temperature and flow $350^{\circ} \mathrm{C}$ and $10 \mathrm{l} / \mathrm{min}$, respectively. The acquisition MS method was multiple reaction monitoring (MRM), performed by collision-induced dissociation (CID) of the precursor ions in the collision cell. Two transitions between the precursor ion and the most abundant product ions were monitored for the identification of BPA, PTA, BPA$\mathrm{d} 16$ and PTA-d4, and the ion transition with relatively higher intensity was selected for quantitation. The collision gas was nitrogen. The negative ion multiple reaction monitoring (MRM) mode was used in the identification of target chemicals. Further details of the MS/MS parameters are listed in Supplementary Table Sx1-2. Data were acquired and processed by MassHunter (ver. 4.1).

Instrumental calibration was verified by the injection of standards at concentrations that ranged from 0.1 to $50 \mathrm{ng} / \mathrm{mL}$ for BPA and from 2.5 to $750 \mathrm{ng} / \mathrm{mL}$ for PTA whereas the concentrations of IS were fixed at 
$200.0 \mathrm{ng} \mathrm{ml}^{-1}$, and the solvent was $\mathrm{MeOH} / \mathrm{H} 2 \mathrm{O}$ (1.5:8.5). The obtained regression coefficient of the calibration curve $(r)$ was $>0.99$. For samples with concentrations above the calibration range, extracts were diluted and reanalysed.

\subsubsection{Quality Assurance and Quality Control}

To minimise background microplastic contamination in the laboratory, protocols laid out by Woodall et al. (2015) were adapted. All laboratory materials used during the sample preparation and extraction were rinsed twice with bidistilled water and covered with tin foil before and after the use. Blue cotton coveralls and headscarves were always worn by analysts to prevent contamination of the samples by synthetic clothing. One procedural blank without sample was performed simultaneously during every working batch of 5 samples by passing solvents and reagents through the entire analytical procedure, including the alkaline depolymerisation step of extraction. Both the TPA and BPA were not found in any of the procedural blanks at concentrations above the method quantification limits. To ensure accuracy of the analytical method, the depolymerisation experiments were performed in triplicate using PET $(300 \mu \mathrm{m})$ and PC $(300 \mu \mathrm{m})$ particles (Goodfellow Cambridge, Ltd., Huntingdon, England) as amounts of BPA and PTA mg released from $0.25 \mathrm{~g}$ of $\mathrm{PC}$ and $0.5 \mathrm{~g}$ of PET particles and without MPs particles to obtain values for procedure blanks following a previously published method of Wang et al. 2017. The depolymerisation efficiency of extraction was checked by fortifying PC and PET particles at $100 \mathrm{mg} / \mathrm{kg}, 150 \mathrm{mg} / \mathrm{kg}, 300 \mathrm{mg} / \mathrm{kg}$ and $1000 \mathrm{mg} / \mathrm{kg}$ in dry bivalve tissue according to Wang et al. 2017 (i.e. depolymerisation of PET and PC yielding PTA and BPA, respectively) (Table 1). The procedure blank showed no detectable background of BPA and PTA. The limits of quantification (LOQ) were calculated from the lowest acceptable calibration standard and a nominal sample weight of $0.5 \mathrm{~g}$ (Table 1 ). The regression coefficient of the calibration curve $(r)$ was $>0.99$.

\subsection{Statistical Analysis}

Tests on contingency tables (XLSTAT 2013.2.04) were applied to statically evaluate the difference between turtle sizes and microparticle occurrences.

The content of microplastics in the liver and fat of loggerhead turtle was statistically analysed for the comparison of two tissues based on the levels of MPs compounds of interest by Wilcoxon signed-rank test, and the correlation between the polymers PET and PC and free available BPA and PTA was analysed by Spearman rank correlations test using the $\mathrm{R}$ statistical software, version 3.5.2 (R Core Team 2018). Concentrations below the LOQs were substituted with a value equal to LOQs divided by the square root of 2 , for the calculation of the mean (Welch $t$ test was used for the comparison of two tissues based on the levels of MPs compounds of interest and Spearman rank correlations test method to compute the correlation between the polymers PET and PC and free available BPA and PTA. Concentrations below the LOQs were substituted with a value equal to LOQs divided by the square root of 2 , for the calculation of the mean.

\section{Results and Discussion}

\subsection{Necropsy Data}

Biometrics of necropsied loggerhead turtles $(N=8)$ are summarised in Table 2. CCL ranged from 30 to $79 \mathrm{~cm}$, with an average value of $57.5 \mathrm{~cm}$. The mean weight was $25.15 \mathrm{~kg}$, varying between 2.8 and $60.3 \mathrm{~kg}$. In general, $87.5 \%$ of specimens showed a good BCS. Seven were identified as female, only one sexually mature.

Five carcasses (62.5\% of animals) showed external trauma due to the anthropogenic activities, such as linear fractures on dorsal scutes of carapace or rhamphotheca and traumatic compression injuries around the fin (entanglement). Despite this, the major pathological lesions were evidenced in the digestive tract and haemolymphatic system. Haemorrhagic gastroenteritis was found in six turtles (75\% of animals), aggravated by the presence of ulcer single or multiple in five cases. In the larger sea turtle (CCL 79), a plastic plug was enveloped in a pocket of the middle mucosa causing a perforation. Numerous fragments of nylon fishing net were discovered in the intestinal tract. In turtle no. 8, a hepatic degeneration was evidenced, while in no. 2 , fatty degenerated hepatocytes were found. In five animals, the spleen presented macroscopic lesions ranging from a congested to a pale appearance. Where histological examination was possible, the damages were attributable to splenitis with necrotizing arteritis and non-specific hyperplastic splenitis, respectively. In animal no. 4 , the thymus was small with a 
Table 1 Limits of quantification (LOQ) and recoveries \pm RSD of the spiked MPs in biota for BPA and PTA

\begin{tabular}{|c|c|c|c|c|c|c|}
\hline MPs & $\begin{array}{l}\text { LOQ for free BPA and } \\
\text { PTA } \mathrm{mg} / \mathrm{kg}\end{array}$ & $\begin{array}{l}\text { LOQ for depolymerised BPA } \\
\text { and PTA } \mathrm{mg} / \mathrm{kg}\end{array}$ & $\begin{array}{l}\text { At } 100 \mathrm{mg} / \mathrm{kg} \\
\text { spiking level }\end{array}$ & $\begin{array}{l}\text { At } 150 \mathrm{mg} / \mathrm{kg} \\
\text { spiking level }\end{array}$ & $\begin{array}{l}\text { At } 300 \mathrm{mg} / \mathrm{kg} \\
\text { spiking level }\end{array}$ & $\begin{array}{l}\text { At } 1000 \mathrm{mg} / \mathrm{kg} \\
\text { spiking level }\end{array}$ \\
\hline PET & 0.25 & 0.25 & 76.0 & 111 & 80.1 & 89.1 \\
\hline $\mathrm{PC}$ & 0.01 & 0.01 & 109 & 99.9 & 110 & 96.2 \\
\hline
\end{tabular}

lardaceous appearance with histological confirmation of thymic atrophy and replacement of adipose tissue.

\subsection{MEP Data}

Apart from no. 1 and no. 2 turtles, that showed empty intestinal tracts, the contents of all other carcasses were collected, and microparticles extracted according to the 4 steps of MEP. Quantitative data on the intestinal content of each animal are reported in Table 3.

After steps 1 and 2, frequency of plastic occurrence (FO) of marine debris in the intestine tracts was $83.3 \%$. The intestine of the turtle no. 7 did not contain any plastic materials. The others ranged from 0.03 to $0.11 \mathrm{~g}$ of plastic litters, not proportionally correlated to the mass of intestinal contents. MPs extracted in the phase 1 , from 5 to $1 \mathrm{~mm}$, were present only in the turtle nos.3, 5, 6 and 8 (Table 4). The most abundant plastic litter was grey foam. The average number of items per turtle was 4.75 .

After extraction, following steps 3 and 4 of MEP, the total number and morphological features (shape and colour) of extracted microparticles (ranging from $0.45 \mu \mathrm{m}$ to $1 \mathrm{~mm}$ ) were assessed by stereomicroscope (Table 5). From all the animals, a total of 623 microparticles were extracted, in particular 408 from supernatant of SW (third step of MEP) and 215 from SW sediments (fourth step of MEP). Those extracted in the SW supernatant were mostly composed by fragments $(85 \%)$, followed by filaments (9\%), films $(5 \%)$ and spheres $(1 \%)$. The most represented colours were blue and black (Fig. 2). From SW sediment fragments were $75 \%$, filaments $18 \%$, films $7 \%$ and spheres $1 \%$. Blue was the most represented colour (Fig. 3). Focusing on single animals, turtle no 8 showed the lowest number of particles (51 items) (Table 5) of which the prevalence was represented by fragments (59\%) (Fig. 4). The highest value of particles was found in animal 5 (241 items) of which fragments represented the $94 \%$. Considering all the animals, fragments were the most representative litter shape $(82.2 \%)$, while fibres, films and pellet were found in lower quantities $(11.1 \%, 6.3 \%$ and $0.5 \%$, respectively). Noticeably, blue (8-65\%), black (10-32\%) and transparent (4-22\%) were the most representative colour of particles found in the intestine of all specimens, while the least representative colours were yellow, orange (both colours found in only two specimens) and brown (found only in a specimen) (Fig. 5). In Fig. 6, some representative pictures of microparticles extracted from intestinal tract of turtles are reported.

The average value found was 89 . The occurrence of ingested microparticles showed values higher than the other already published, probably due to the filtered dimensions. In fact, this is the first study on microparticles ingested by loggerhead turtles until $0.45 \mu \mathrm{m}$ in the Adriatic Sea. Digka et al. stated an average value of $7.94 \pm 3.85$ item until $300 \mu \mathrm{m}$ in loggerhead turtle stranded along the Greek coast of the east Mediterranean Sea (Digka et al. 2020). Duncan et al. (2018) also showed almost the same value.

\subsection{Vibrational Characterisation: ATR-FTIR and RMS}

Based on the coupling of ATR-FTIR spectroscopy and Raman microspectroscopy, it was possible to determine the chemical composition of all microparticles both (ranging from $0.45 \mu \mathrm{m}$ and $1 \mathrm{~mm}$, and $>1 \mathrm{~mm}$ ). These analyses detected 19 different polymers, 4 type of cellulose and 4 minerals, differently distributed among animals (Table 6). Among 19 polymers, 3 were recorded at higher frequency, including polyester (PL; 100\% of animals), high density polyethylene (HDPE; $50 \%$ of animals) and polypropylene (PP; $50 \%$ of animals). The most impacted animals were nos. 5, 8 and 4 in which 9, 7 and 6 different polymers were recorded, respectively. On the contrary, the least impacted specimen was no. 7 in which only polyester particles were found. Noticeably, cellulose and its derivates and minerals were found in $83 \%$ and $50 \%$ of specimens respectively.

Based on MPs Raman analysis, the presence of 10 different pigments was also detected: 5 blue pigments, 4 red and 1 black. The most represented pigments were 


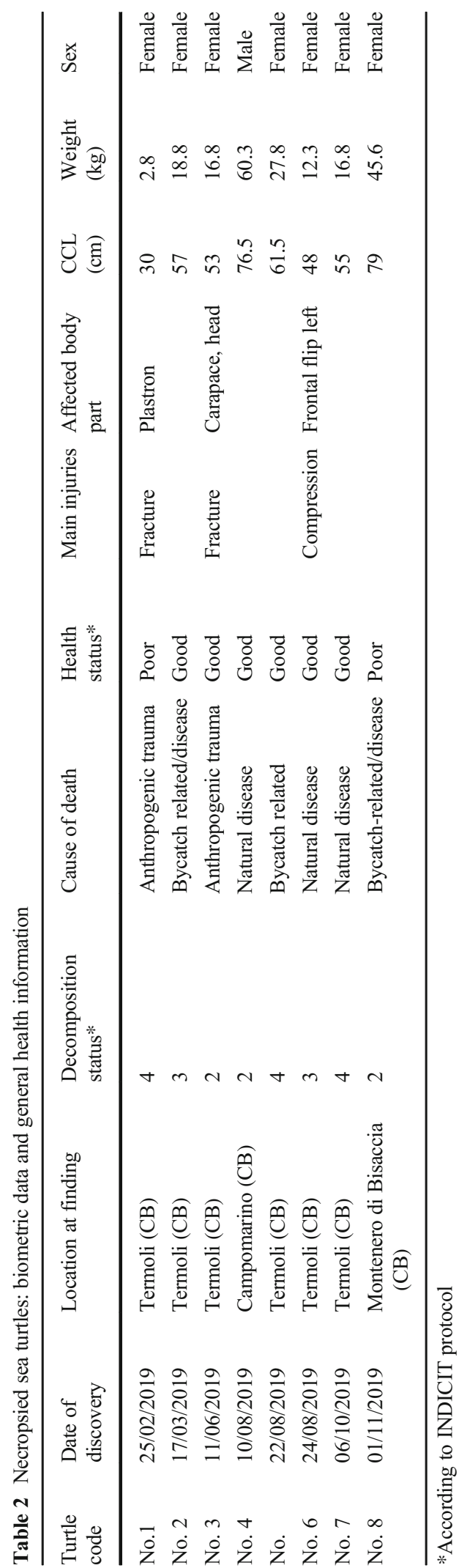

the copper phthalocyanine (Pigment Blue 15; C.I. Constitution 74,160) (100\% of animals) and the Pigment Black 9; C.I. Constitution 77,267 (50\% of animals) (Table 7).

Raman and ATR-spectra of most represented polymers and pigments are shown in Fig. 7.

Considering the size of the investigated turtles, in loggerheads CCL $<60 \mathrm{~cm}$, polyester (PL) was the most abundant polymer type (39.4\%); instead, in animals with $\mathrm{CCL}>60 \mathrm{~cm}$, it was high density polyethylene (PP) $(34.4 \%)$.

Finally, the percentage of sinking (i.e. PET, PU) and floating items in the loggerheads CCL $<60 \mathrm{~cm}$ were, respectively, $55 \%$ and $45 \%$, in loggerheads CCL > $60 \mathrm{~cm}$ were $67 \%$ and $33 \%$. There was no difference statically significant between two sizes and the presence of floating and sinking microparticles (Chi-square test, $p>0.05)$.

\subsection{PET and PC Data}

The obtained recoveries of BPA and PTA released from $0.25 \mathrm{~g}$ of PC and $0.5 \mathrm{~g}$ PET particles were $93.0 \%$ and $90.0 \%$, respectively, indicating good depolymerisation efficiency. The recoveries of PC and PET fortified into samples were in the range of $76.0-111 \%$, respectively (Table 1). The applied method principles with direct MPs extraction ensure the analysing efficiency directly preventing MPs loss as well as the detection of the smallest MPs fractions that would be able to penetrate into the animal tissues. A typical chromatogram of free and depolymerised TPA and BPA can be found in Fig. 8.

In order to calculate PC and PET MPs in the fat and liver samples of $C$. caretta from the Adriatic Sea, the concentrations of original free form BPA and PTA were deducted. Concentrations of free BPA and PTA found in the selected tissue types range from roughly $0.026 \mathrm{mg} / \mathrm{kg}$ in the liver to $0.805 \mathrm{mg} / \mathrm{kg}$ in abdominal fat tissue and $0.775 \mathrm{mg} / \mathrm{kg}$ in the liver to $48.91 \mathrm{mg} / \mathrm{kg}$ in abdominal fat tissue, respectively (Table 8). The maximum obtained PC MPs in the fat tissue was calculated to be $1.383 \mathrm{mg} / \mathrm{kg}$, while the PET was $59.95 \mathrm{mg} / \mathrm{kg}$ (Table 8). The significantly higher contents of PC have been detected in abdominal fat tissue compared to liver tissues whereas the PET levels had not revealed significant differences between the examined tissues. There was no significant correlation between the concentrations of PET and PC in both examined tissues, which suggested 
Table 3 Quantitative data of intestinal contents to be extracted

\begin{tabular}{|c|c|c|c|c|c|c|c|}
\hline \multirow[b]{2}{*}{$\begin{array}{l}\text { Turtle } \\
\text { code }\end{array}$} & \multicolumn{5}{|l|}{ Steps 1 and 2} & \multirow{2}{*}{$\begin{array}{l}\text { Step } 3 \\
\text { Volume of SW filtered } \\
\text { aqueous phase }(\mathrm{ml})\end{array}$} & \multirow{2}{*}{$\begin{array}{l}\text { Step } 4 \\
\text { Weight of SW } \\
\text { sediment }(\mathrm{g})\end{array}$} \\
\hline & $\begin{array}{l}\text { Mass of full } \\
\text { intestine (g) }\end{array}$ & $\begin{array}{l}\text { Dry of full } \\
\text { intestine }(\mathrm{g})\end{array}$ & $\begin{array}{l}\text { Plastic litter mass in } \\
\text { the intestine }(\mathrm{g})\end{array}$ & $\begin{array}{l}\text { Weight of } \\
\text { scrubbing water } \\
\text { (g) }\end{array}$ & $\begin{array}{l}20 \% \mathrm{w} / \mathrm{w} \text { of } \\
\text { scrubbing water } \\
(\mathrm{SW})\end{array}$ & & \\
\hline No. 3 & 537.0 & 28.72 & 0.11 & 8477 & 1695.4 & 1600 & 7 \\
\hline No. 4 & 1550.9 & 140.08 & 0.04 & 26,324 & 5210.8 & 5000 & 55 \\
\hline No. 5 & 956.5 & 368.13 & 0.03 & 10,752 & 2150.4 & 1500 & 7 \\
\hline No. 6 & 265.7 & 29.23 & 0.03 & 6564 & 1312.8 & 1200 & 10 \\
\hline No. 7 & 52.4 & 9.19 & 0.00 & 610 & 122.0 & 100 & 5 \\
\hline No. 8 & 1550.9 & 140.08 & 0.90 & 6729 & 1345.0 & 1250 & 10 \\
\hline
\end{tabular}

that the sources of PET and PC are different. The monomers of two classes of microplastics, PTA and BPA, (i.e. free forms) were also characterised with a similar trend. On the other hand, the free PTA was higher in the liver than in fat tissue while free BPA was similar in both tissues.

FTIR and Raman spectroscopy analysis of gastrointestinal content of the animals revealed polyester and PET, both polymers of PTA, in all animals with gut material found and being the most abundant microplastics. PTA has been used mainly as a raw material for polyester fibre, but lately it has been exploited for various uses in the non-fibre field for PET (polyethylene terephthalate)-bottles, PET-films, engineering of plastics and as poultry feed additives (Bandet al. 2011.) PET content reported after LC-MS/ MS analysis includes both polyethylene terephthalate and polyester polymers. PET polymers were also found
Table 4 MPs (ranging from 1 to $5 \mathrm{~mm}$ ) extracted during the phase no. 1 from sea turtles. Litter categories: industrial plastic (indpla-pellet and granules); sheet-like categories (use she-bags, foil, agriculture sheets); threadlike materials (use thr-ropes, filaments, ghost fishing gear); foamed plastics (use foa-PS foam or foamed soft rubber); fragments (use fra-hard plastic items); other user plastic (use poth-elastics, dense rubber, balloon pieces etc.)

\begin{tabular}{|c|c|c|c|c|c|c|c|c|}
\hline \multirow[b]{2}{*}{ Plastics } & \multicolumn{2}{|c|}{ Turtle no. 3} & \multicolumn{2}{|c|}{ Turtle no. 5} & \multicolumn{2}{|c|}{ Turtle no. 6} & \multicolumn{2}{|c|}{ Turtle no. 8} \\
\hline & $\begin{array}{l}\text { No } \\
\text { items }\end{array}$ & $\begin{array}{l}\text { Dimension } \\
\text { and colour }\end{array}$ & $\begin{array}{l}\text { No } \\
\text { items }\end{array}$ & $\begin{array}{l}\text { Dimension } \\
\text { and colour }\end{array}$ & $\begin{array}{l}\text { No } \\
\text { items }\end{array}$ & $\begin{array}{l}\text { Dimension } \\
\text { and colour }\end{array}$ & $\begin{array}{l}\text { No } \\
\text { items }\end{array}$ & $\begin{array}{l}\text { Dimension } \\
\text { and colour }\end{array}$ \\
\hline IndPla & 2 & $\begin{array}{l}\sqrt{ } 3 \mathrm{~mm} ; \\
\sqrt{ } 3 \mathrm{~mm} ; \\
\text { (all yellow) }\end{array}$ & & & 4 & $\begin{array}{l}\sqrt{ } 1.1 \mathrm{~mm} ; \\
\sqrt{ } 1.1 \mathrm{~mm} ; \\
\sqrt{ } 1.1 \mathrm{~mm} ; \\
\sqrt{ } 1.1 \mathrm{~mm} ; \\
\text { (all clear/green) }\end{array}$ & & \\
\hline Use she & & & 4 & $\begin{array}{l}\sqrt{4} \mathrm{~mm} ; \\
\sqrt{4} \mathrm{~mm} ; \\
\sqrt{4} \mathrm{~mm} ; \\
\sqrt{4} \mathrm{~mm} . \\
\text { (all yellow). }\end{array}$ & & & & \\
\hline \multicolumn{9}{|l|}{ Use thr } \\
\hline Use foa & 2 & $\begin{array}{l}\sqrt{4} \mathrm{~mm} \\
\sqrt{4} \mathrm{~mm} \\
\text { (all grey) }\end{array}$ & 2 & $\begin{array}{l}\sqrt{ } 1.2 \mathrm{~mm} ; \\
\sqrt{ } 1.2 \mathrm{~mm} ; \\
\text { (all grey) }\end{array}$ & 3 & $\begin{array}{l}\sqrt{ } 2 \mathrm{~mm} ; \\
\sqrt{ } 1.5 \mathrm{~mm} ; \\
\sqrt{ } 1.8 \mathrm{~mm} \\
\text { (all grey) }\end{array}$ & 1 & $\sqrt{ } 4 \mathrm{~mm}$ (grey) \\
\hline Use frag & 1 & $\sqrt{5} \mathrm{~mm}$ (clear) & & & & & & \\
\hline Other (use & & & & & & & & \\
\hline
\end{tabular}


Table 5 Number of microparticles (ranging from $0.45 \mu \mathrm{m}$ to $1 \mathrm{~mm}$ ) extracted during steps 3 and 4 of MEP from each turtle ( $F l$, filament; $F m$, film; $F r$, fragment; $S p$, sphere)

\begin{tabular}{|c|c|c|c|c|c|c|c|c|c|c|c|}
\hline \multirow[t]{2}{*}{ Turtle code } & \multicolumn{5}{|c|}{ Step 3 (SW supernatant) (a) } & \multicolumn{5}{|c|}{ Step 4 (SW sediment) (s) } & \multirow[b]{2}{*}{ Total $(a+s)$} \\
\hline & $\mathrm{Fl}$ & $\mathrm{Fm}$ & Fr & $\mathrm{Sp}$ & Tot (a) & $\mathrm{Fl}$ & Fm & $\mathrm{Fr}$ & $\mathrm{Sp}$ & Tot $(\mathrm{s})$ & \\
\hline No. 3 & 7 & 4 & 46 & & 57 & 2 & & 16 & & 18 & 75 \\
\hline No. 4 & 6 & 4 & 7 & & 17 & 1 & 6 & 63 & 1 & 71 & 88 \\
\hline No. 5 & 5 & 8 & 197 & 1 & 211 & & & 30 & & 30 & 241 \\
\hline No. 6 & 2 & 5 & 31 & 1 & 39 & 1 & 4 & 35 & & 40 & 79 \\
\hline No. 7 & 12 & & 48 & & 60 & 19 & 1 & 9 & & 29 & 89 \\
\hline No. 8 & 6 & & 18 & & 24 & 8 & 7 & 12 & & 27 & 51 \\
\hline Tot & 38 & 21 & 347 & 2 & 408 & 31 & 18 & 165 & 1 & 215 & 623 \\
\hline
\end{tabular}

by LC-MS/MS analysis in liver or abdominal fat tissue of all animals including those with empty gut.

Although PC was not found in the gastrointestinal tract by spectroscopy analysis, it was found by LC-MS/MS in fat and liver tissues. PC was detected in $50 \%$ of animals, and free BPA in all (Table 8). A major prevalence of all the determined compounds were registered in abdominal fat tissue, although only PC compound was significantly higher in abdominal tissue $(p<0.05)$, except for free PTA with liver tissue being the most contaminated $(p<0.05)$ (Table 8$)$.

Similar findings reported Duncan et al. (2018) who found, in the gut of the loggerhead turtle from the East Mediterranean Sea, the polyester fibres and polyethylene-terephthalate and did not find polycarbonate as in the Pacific Ocean but found PC in the loggerhead turtle from the Atlantic Ocean. The most impacted animals were nos. 2, 4 and 1, the latter being characterised by the highest presence of PC and PET polymers in both tissues, except for PET amounts in liver tissues recorded at the highest levels in animal no. 8. Animal no. 4 revealed the second highest amounts of PET for both examined tissues, but in animal no. 2, the second highest levels of PC in abdominal fat tissue and determined PET amounts in liver and fat tissues were detected. In general, the major incidence of free BPA was detected in fat of the animal no. 1 and free PTA in the liver of the animal no. 3, respectively.

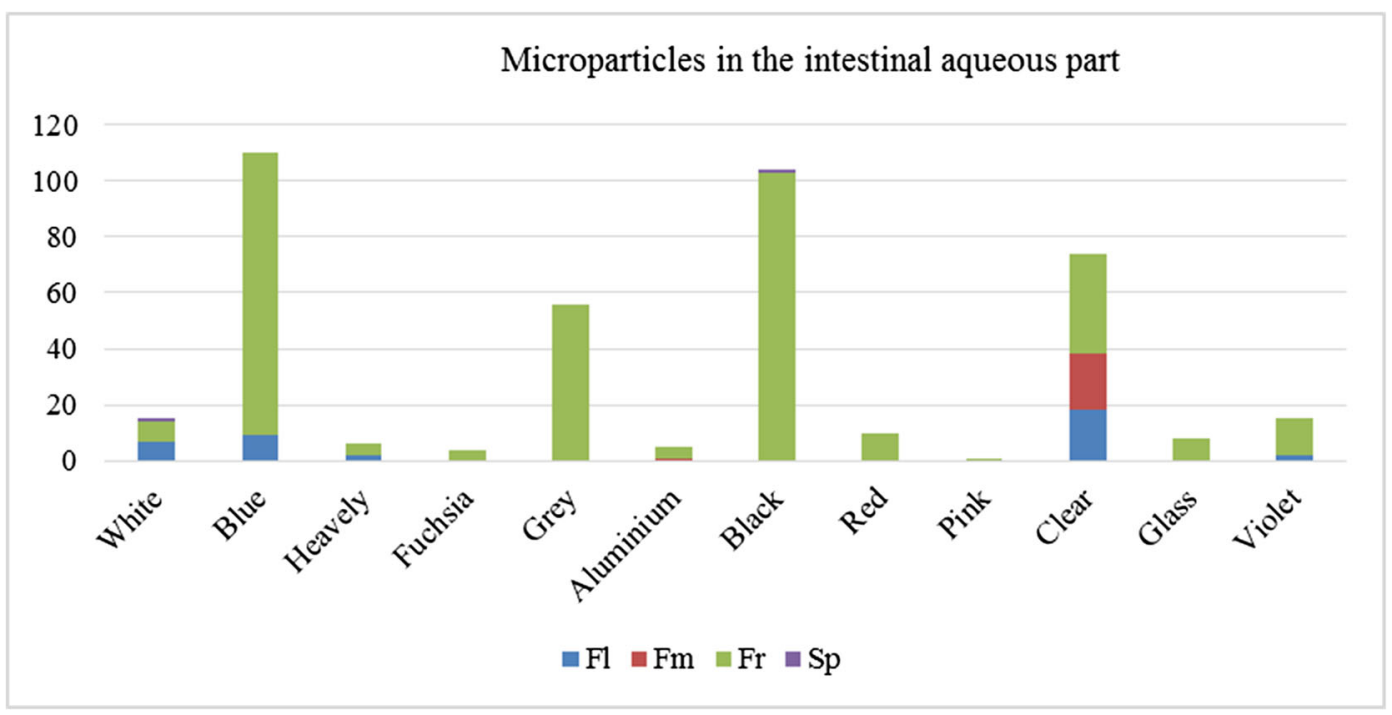

Fig. 2 Number of microparticles (ranging from $0.45 \mu \mathrm{m}$ to $1 \mathrm{~mm}$ ) per colour extracted from intestinal content following the third step of MEP (Fl, filament; Fm, film; Fr, fragment; Sp, sphere) 


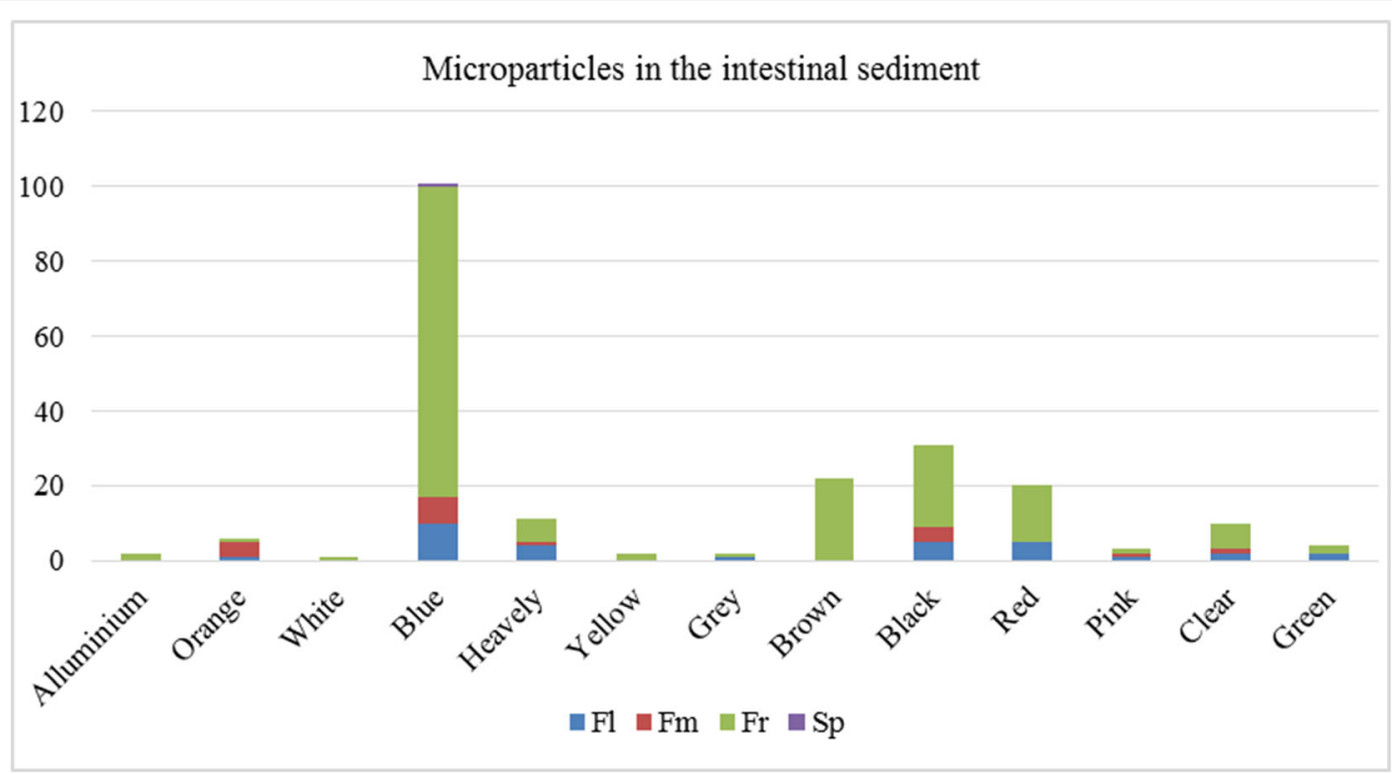

Fig. 3 Number of microparticles (ranging from $0.45 \mu \mathrm{m}$ to $1 \mathrm{~mm}$ ) per colour extracted from sediment of the intestinal content following the fourth step of MEP (Fl, filament; Fm, film; Fr, fragment; Sp, sphere)

\subsection{PET, PC, Free BPA and Free PTA Data per Each}

Turtle Size

All data on chemical contamination in fat and liver tissues were correlated to turtle sizes. The specimen no. 8 (CCL equal to $79 \mathrm{~cm}$ ) was the only adult necropsied, the others belonged to juvenile life stage.
Foraging behaviours of loggerhead turtles could change at almost CCL of $40 \mathrm{~cm}$; they leave the open sea and surface water for the neritic zones (Casale et al. 2011; Frick et al. 2009; Margaritoulis et al. 2003). The turtle no. $1(\mathrm{CCL} 30 \mathrm{~cm})$ was the unique juvenile that did not supposedly leave open sea yet. It was not possible to prove within food remains the foraging behaviour of this

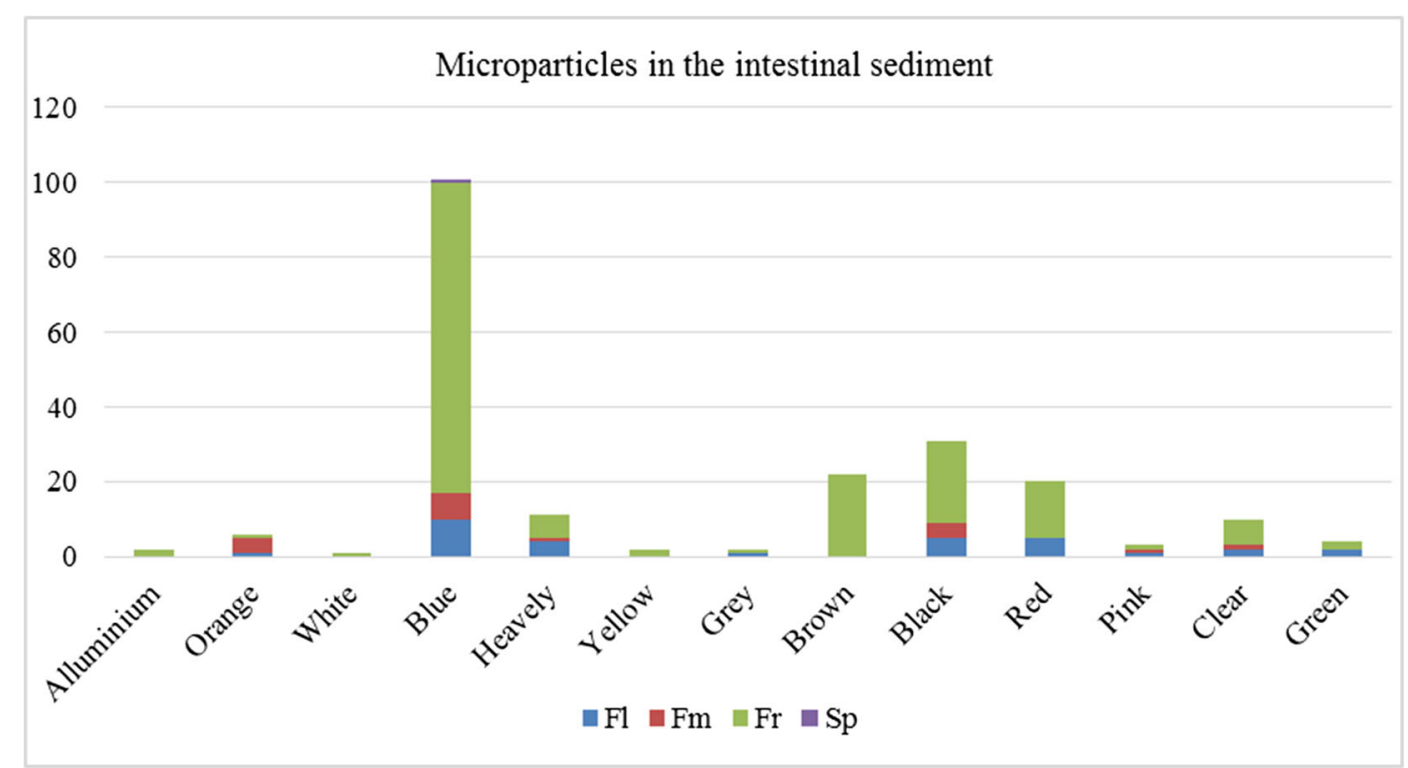

Fig. 4 Shape distribution of microparticles (ranging from $0.45 \mu \mathrm{m}$ to $1 \mathrm{~mm}$ ) extracted during the steps 3 and 4 of MEP from each numbered turtle 


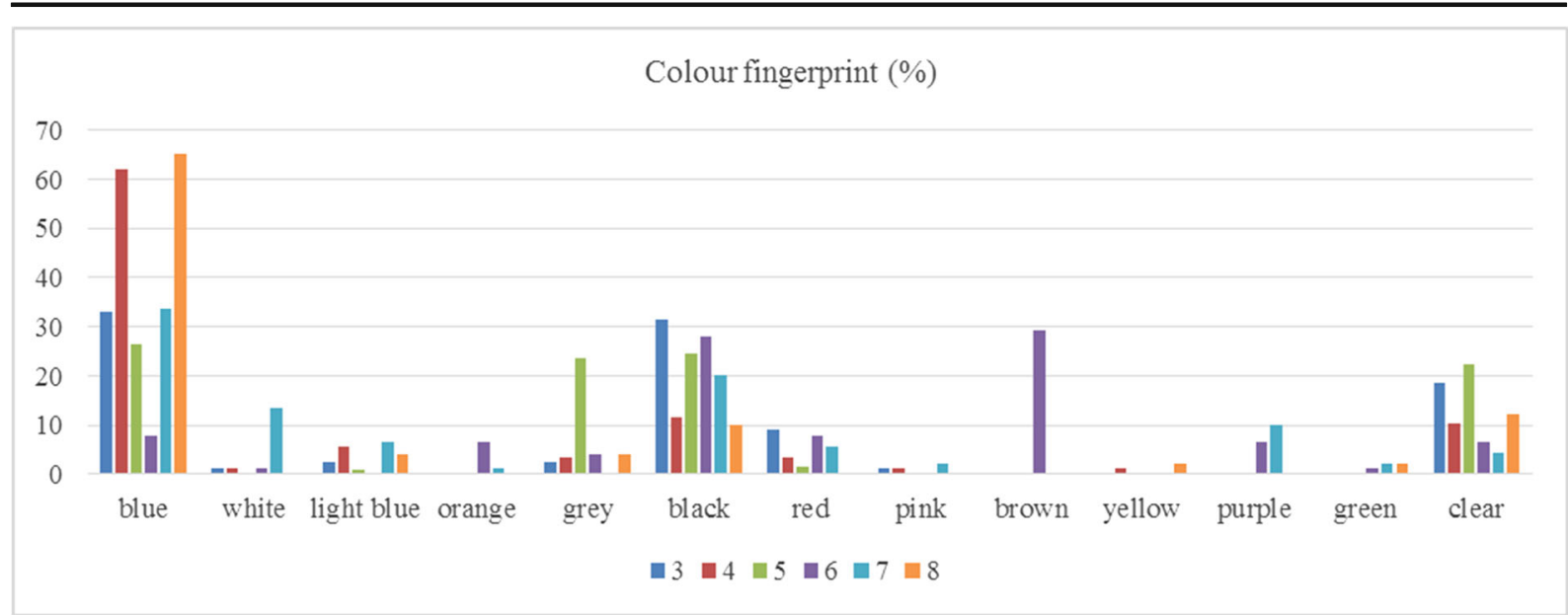

Fig. 5 Colour distribution of microparticles (ranging from $0.45 \mu \mathrm{m}$ to $1 \mathrm{~mm}$ ) extracted during the steps 3 and 4 of MEP from each numbered turtle

animal, due to its gastro-intestinal tract, as well as that of turtle no. 2, was empty. Conversely, food remnants found in turtle no. 4 came from water column. In the gastro-intestinal contents of animal nos. 3, 5-8, residues of benthic organisms were found confirming that these turtles surely left the open sea for neritic zones. The contaminant exposure is influenced by the swimming behaviour of turtles; the adult could be more exposed to

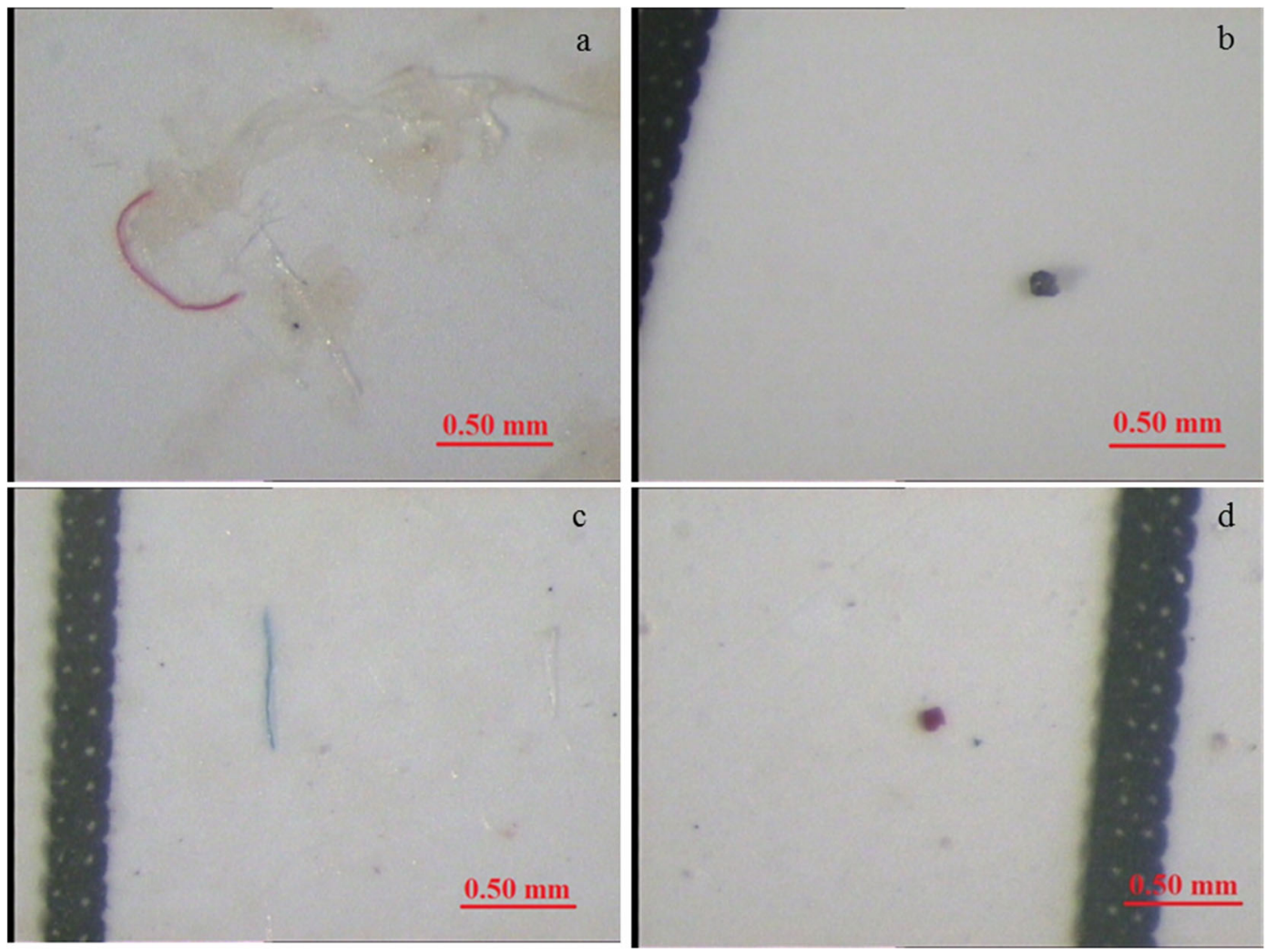

Fig. 6 Filter pictures by stereomicroscope $\times 40$ magnification. a Red filament in sediment of turtle no. 7. b Blue fragment in aqueous phase of turtle no. 4. c Heavenly filament in sediment of turtle no. 7. d Red fragment in sediment of turtle no. 5 
Table 6 ATR-FTIR (MPs $>1 \mathrm{~mm}$ ) and RAMAN (MPs $<1 \mathrm{~mm}$ ) macromolecular characterisation of total MPs extracted following all the 4 steps of MEP. Aqueous $(A)$ and sediment $(S)$ fractions of SW were considered

\begin{tabular}{|c|c|c|c|c|c|c|c|c|c|c|c|c|c|c|c|c|c|c|}
\hline \multirow[t]{3}{*}{ Material } & \multicolumn{3}{|c|}{ Turtle no. 3} & \multicolumn{3}{|c|}{ Turtle no. 4} & \multicolumn{3}{|c|}{ Turtle no. 5} & \multicolumn{3}{|c|}{ Turtle no. 6} & \multicolumn{3}{|c|}{ Turtle no. 7} & \multicolumn{3}{|c|}{ Turtle no. 8} \\
\hline & \multirow[t]{2}{*}{$>1 \mathrm{~mm}$} & \multicolumn{2}{|c|}{$<1 \mathrm{~mm}$} & \multirow[t]{2}{*}{$>1 \mathrm{~mm}$} & \multicolumn{2}{|c|}{$<1 \mathrm{~mm}$} & \multirow[t]{2}{*}{$>1 \mathrm{~mm}$} & \multicolumn{2}{|c|}{$<1 \mathrm{~mm}$} & \multirow[t]{2}{*}{$>1 \mathrm{~mm}$} & \multicolumn{2}{|c|}{$<1 \mathrm{~mm}$} & \multirow[t]{2}{*}{$>1 \mathrm{~mm}$} & \multicolumn{2}{|c|}{$<1 \mathrm{~mm}$} & \multirow[t]{2}{*}{$>1 \mathrm{~mm}$} & \multicolumn{2}{|c|}{$<1 \mathrm{~mm}$} \\
\hline & & $\mathrm{A}$ & $\mathrm{S}$ & & A & S & & A & S & & A & S & & A & S & & A & S \\
\hline \multicolumn{19}{|l|}{$\mathrm{PC}$} \\
\hline PL & & $\mathrm{X}$ & $\mathrm{X}$ & & & $\mathrm{X}$ & & $\mathrm{X}$ & & & X & $\mathrm{X}$ & & $\mathrm{X}$ & $X$ & & $\mathrm{X}$ & X \\
\hline PU & & & & & $\mathrm{X}$ & & & & & & & & & & & & & $\mathrm{X}$ \\
\hline PVAc & & & & & & & & & X & & & & & & & & & \\
\hline PP & & & & & & & & $\mathrm{X}$ & $\mathrm{X}$ & & & $\mathrm{X}$ & & $\mathrm{X}$ & & $\mathrm{X}$ & & \\
\hline PET & & & & $\mathrm{X}$ & & & & $\mathrm{X}$ & & & & & & $\mathrm{X}$ & & & & \\
\hline HDPE & & & & & & & & $\mathrm{X}$ & & & $\mathrm{X}$ & & & $\mathrm{X}$ & & $\mathrm{X}$ & $\mathrm{X}$ & $\mathrm{X}$ \\
\hline PEVA & & & & & & & & & & & $\mathrm{X}$ & & & & & & & \\
\hline $\mathrm{PE}$ & & & & & $\mathrm{X}$ & & $\mathrm{X}$ & & & & & & & & & & & $\mathrm{X}$ \\
\hline $\mathrm{PF}$ & & & & & & & $\mathrm{X}$ & & & & & & & & & & & \\
\hline $\mathrm{CR}$ & & & & & & & $\mathrm{X}$ & & & & & & & & & & & \\
\hline UF & & & & & & & & & & & & & & & & $\mathrm{X}$ & & \\
\hline PIB & & & & & & & & & & & & & & & & $\mathrm{X}$ & & \\
\hline PVDC & & & & & & & $\mathrm{X}$ & & & & & & & & & & & \\
\hline PS & $\mathrm{X}$ & & & & & & & & & $\mathrm{X}$ & & & & & & & & \\
\hline PPTA & $\mathrm{X}$ & & & & & & & & & & & & & & & & & \\
\hline SBIR & & & & $\mathrm{X}$ & & & & & & & & & & & & & & \\
\hline EPDP & & & & X & & & & & & & & & & & & & & \\
\hline $\mathrm{PA}$ & & & & $\mathrm{X}$ & & & & & & $\mathrm{X}$ & & & & & & & & \\
\hline $\mathrm{C}$ & & & & & & & & & & & & & & & $\mathrm{X}$ & & & \\
\hline $\mathrm{CN}$ & & & & & $\mathrm{X}$ & & & $\mathrm{X}$ & & & $\mathrm{X}$ & $\mathrm{X}$ & & & & & & \\
\hline $\mathrm{CA}$ & & & & & & & & & & & $\mathrm{X}$ & & & & & & & \\
\hline lyocell (cellulose) & & & & & & & & & & & & & & & $X$ & & & \\
\hline Aluminium oxide & & & & & & & & & X & & & $\mathrm{X}$ & & & & & $\mathrm{X}$ & \\
\hline Quartz & & & & & & & & & & & & & & & & & $\mathrm{X}$ & \\
\hline Orthoclase & & & $\mathrm{X}$ & & & & & & & & & & & $\mathrm{X}$ & & & & \\
\hline AlmandinepEssartine & & & & & & & & $\mathrm{X}$ & & & & & & & & & & \\
\hline Goethite & & $\mathrm{X}$ & $\mathrm{X}$ & & & & & & & & & & & & & & & \\
\hline
\end{tabular}

$X$, presence; $P L$, polyester; $P U$, polyurethane; $P V A c$, polyvinylacetate; $P U R$, polyurethane; $P P$, polypropylene; $P E T$, poly(ethylene glycolterephthalate); HDPE, high-density polyethylene; $P E V A$, poly(ethylene-co-vinyl acetate); $P E$, polyethylene; $P P T A$, poly(pphenyleneterephthalamide); $P S$, polystyrene; $S B I R$, styrene-butadiene-isopropene rubber; $E P D P$, ethylene-propylene diene terpolymer mixture; $P A$, polyamide; $P F$, formaldehyde resin; $P V D C$, polyvinylidene chloride; $C R$, polychloroprene (neoprene); $U F$, ureaformaldehyde resin; $P I B$, poly(ethylene-co-isobutyethylene); $C$, cellulose; $C N$, nitrocellulose; $C A$, cellulose triacetate

sinking MPs or polymers adsorbed on the sediments, the youngest to floating MPs and subjected to coastal contaminants.

The smallest turtle necropsied (turtle no. 1) had the highest levels of PC and BPA free in both examined tissues and the highest level of PET in the abdominal fat tissue (Figs. 9, 10, and 11).
PET was present in fat of all animals except in largest animal (no. 8), and in the liver of animal nos. 2, 4, 5 and 8 (Fig. 10). Relationship between the fat and liver PET content and the animal size was observed. The smallest animal (no. 1) had a high level of PET in the fat and no PET in the liver, while the biggest animal (no. 8) had PET only in the liver and no PET in the fat (Fig. 10). 
Table 7 RAMAN pigment characterisation of MPs extracted following steps 3 and 4 of MEP. Aqueous $(A)$ and sediment $(S)$ fractions were considered

\begin{tabular}{|c|c|c|c|c|c|c|c|c|c|c|c|c|}
\hline \multirow[b]{2}{*}{ Pigment } & \multicolumn{2}{|c|}{ Turtle no. 3} & \multicolumn{2}{|c|}{ Turtle no. 4} & \multicolumn{2}{|c|}{ Turtle no. 5} & \multicolumn{2}{|c|}{ Turtle no. 6} & \multicolumn{2}{|c|}{ Turtle no. 7} & \multicolumn{2}{|c|}{ Turtle no. 8} \\
\hline & A & $\mathrm{S}$ & A & $\mathrm{S}$ & A & $\mathrm{S}$ & A & $\mathrm{S}$ & A & $\mathrm{S}$ & A & $\mathrm{S}$ \\
\hline AV & & & & $X$ & & & & & & & $X$ & $X$ \\
\hline $\mathrm{CP}$ & $X$ & & & $\mathrm{X}$ & & $\mathrm{X}$ & & $\mathrm{X}$ & & $\mathrm{X}$ & & $\mathrm{X}$ \\
\hline SB & & & & & & & & & & & & $\mathrm{X}$ \\
\hline PT & & & & & & & & & & & & $\mathrm{X}$ \\
\hline AR & & & & & & & & & & $\mathrm{X}$ & & \\
\hline PR & & & & & & & & & & $\mathrm{X}$ & & \\
\hline $\mathrm{AB}$ & & & & & $\mathrm{X}$ & & & & $\mathrm{X}$ & & & \\
\hline PB & $\mathrm{X}$ & & & $\mathrm{X}$ & & & & & $X$ & & & \\
\hline DT & & & & & & $\mathrm{X}$ & & & & & & \\
\hline $\mathrm{RB}$ & & & $X$ & & & & & & & & & \\
\hline
\end{tabular}

$X$, presence; $A V$, Azoviolet (4-(4- nitrophenylazo)resorcinol; $C P$, copper phthalocyanine (Pigment blue 15; C.I. Constitution 74,160); $S B$, Solvent blue 38 (C.I. Constitution 74,180); PT, Phthalocyanine (Pigment blue 16; C.I. Constitution 74,100); AR, Acid red 26 (C.I. Constitution 16,150); PR, Pigment red 14 (C.I. Constitution 12,380); AB, Acid blue 158; PB, Pigment black 9 (C.I. Constitution 77,267); DT, diiron trioxide (Pigment 101/102; C.I. Constitution 77,491); RB, Reactive blue 19 (C.I. Constitution 61,200)

These results suggest the animal developed the mechanisms to decrease PET with the size.

PC was found in fat of animal nos. 1,5 and 7, and in the liver of the two smallest animals nos. 1 and 2 (Fig. 11). Those results suggesting bigger animals could
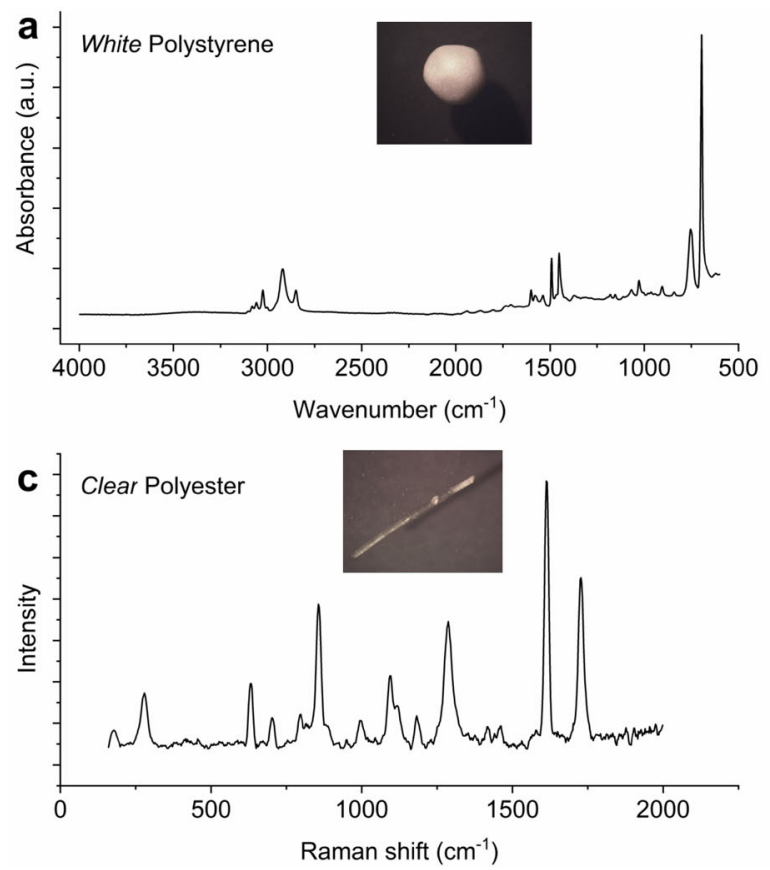

exclude the PC from entering the liver and the possibility of accumulating PC in fat.

Scientific literature on toxicological characterisation of PTA (Bang et al. 2011) showed that its content in tissues and plasma was low, higher in the liver and
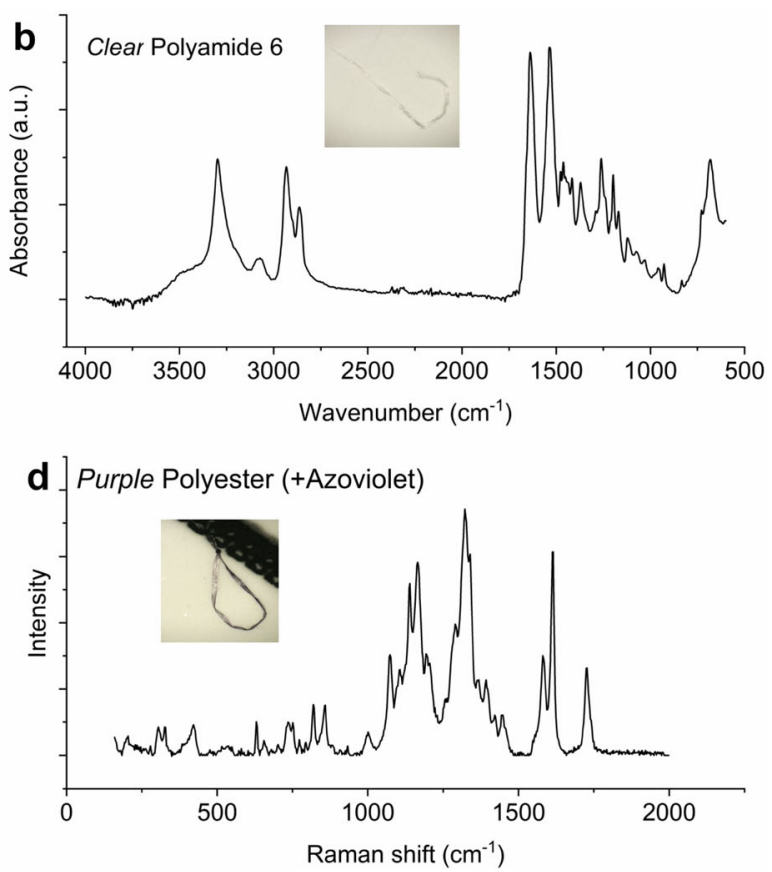

Fig. 7 Representative microphotographs and ATR-FTIR/RMS spectra of four found microplastics. a White polyester sphere. b Clear polyamide fibre. $\mathbf{c}$ Clear polyester fibre. $\mathbf{d}$ Purple (Azoviolet pigment) polyester fibre 

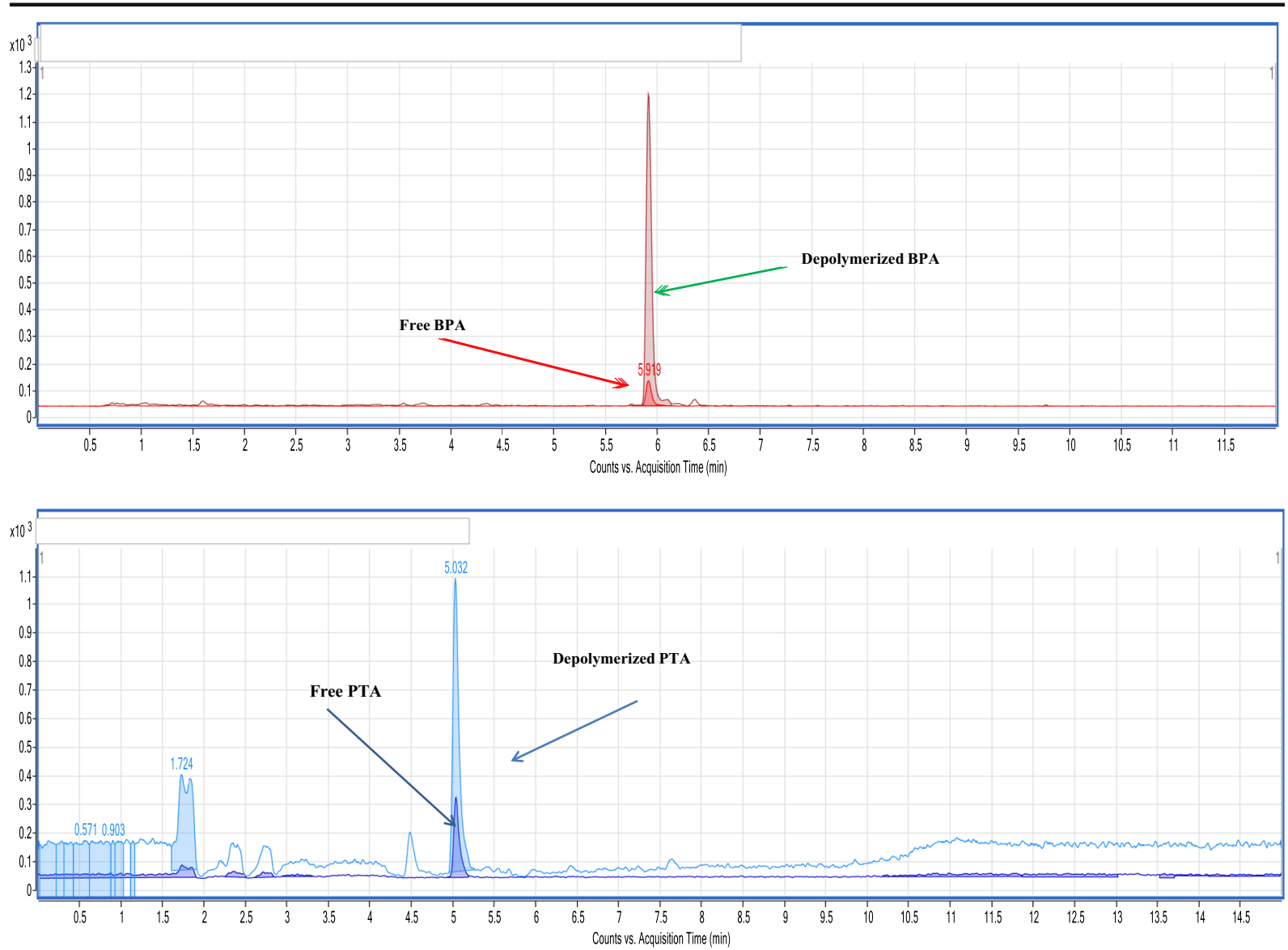

Fig. 8 UPLC-MS/MS chromatograms of free and depolymerised BPA and PTA in spiked biota samples (the sample of depolymerised BPA and TPA were diluted 10 times prior to analysis)

kidney (Hoshi and Kuretani 1968). Moreover, it is rapidly excreted in urine unmetabolised (Hoshi and Kuretani 1967). Free PTA was found in the liver of all necropsied animals, except in oldest animal, no. 8, that showed hepatic degeneration, it was found in the liver of animal nos. 1, 4 and 8 (Fig. 12). Free PTA higher in the liver than in fat tissue indicates PTA metabolizing and/ or excreted. That was opposite to the findings of Savoca et al. (2018), who found the highest levels of the orthophthalic acid esters in fat tissue of $C$. caretta. All animals of $C$. caretta in this study had similar or lower liver levels of PTA free than the levels of esters of ortho-PA previously found by Savoca et al. (2018), indicating that para-phtalic acid as phtalates is abundant in the Mediterranean Sea, and sea turtle is a suitable organism for the assessment of the spatial exposure of para-phtalic acid as well.
BPA is a pseudo-persistent substance that degrades in a short time in water. As it is continuously discharged into the environment, it is ubiquitous, mainly in the anthropised areas such as coastal marine area (Flint et al. 2012). Juveniles of $C$. caretta swim in these areas and they are most probably exposed to BPA. In fact, the highest value of free BPA was found in the youngest animal and in fat of all animals, except animal no. 5. (Fig. 11). Liver-free BPA was found in animal nos. 1, 36 and 8 . Free-BPA levels were similar in the liver and fat of all animals (Table 8). According to Flint et al. (2012), relatively little environmental BPA occurs in biota, and at low doses, BPA is biodegraded or metabolised; so, bioaccumulation occurs only at high doses. Data on necropsied turtles suggest some accumulation of free BPA in fat and slight decrease of fat content with the size of the animal. 
Table 8 Concentrations of free BPA, polycarbonate (PC), free PTA and polyethylene terephthalate (PET) in the liver (L) and fat samples (F) of loggerhead (Caretta caretta) $(\mathrm{mg} / \mathrm{kg})$

\begin{tabular}{|c|c|c|c|c|}
\hline \multirow[t]{2}{*}{ Samples of numbered turtles } & \multicolumn{4}{|c|}{ Concentration $\mathrm{mg} / \mathrm{kg} \pm \mathrm{SD}$} \\
\hline & Free BPA & $\mathrm{PC}$ & Free PTA & PET \\
\hline L1 & $0.246 \pm 0.035$ & $0.621 \pm 0.048$ & $0.77 \pm 0.075$ & $<0.29$ \\
\hline $\mathrm{F} 1$ & $0.805 \pm 0.075$ & $1.30 \pm 0.11$ & $1.08 \pm 0.065$ & $58.86 \pm 1.55$ \\
\hline L2 & $0.256 \pm 0.027$ & $<0.01$ & $40.00 \pm 2.71$ & $10.58 \pm 0.34$ \\
\hline $\mathrm{F} 2$ & $<0.01$ & $0.507 \pm 0.054$ & $3.99 \pm 0.184$ & $2.99 \pm 0.27$ \\
\hline L3 & $0.026 \pm 0.007$ & $<0.01$ & $48.83 \pm 1.84$ & $<0.29$ \\
\hline F3 & $0.197 \pm 0.018$ & $<0.01$ & $5.77 \pm 0.273$ & $2.52 \pm 0.29$ \\
\hline L4 & $<0.01$ & $<0.01$ & $24.19 \pm 2.11$ & $<0.29$ \\
\hline F4 & $0.116 \pm 0.011$ & $0.513 \pm 0.046$ & $1.595 \pm 0.14$ & $3.02 \pm 0.032$ \\
\hline L5 & $0.032 \pm 0.009$ & $<0.01$ & $5.25 \pm 0.260$ & $<0.29$ \\
\hline F5 & $0.070 \pm 0.013$ & $<0.01$ & $9.56 \pm 0.533$ & $3.68 \pm 0.35$ \\
\hline L6 & $<0.01$ & $0.447 \pm 0.038$ & $7.59 \pm 0.392$ & $1.50 \pm 0.15$ \\
\hline F6 & $0.200 \pm 0.021$ & $<0.01$ & $1.075 \pm 0.123$ & $1.67 \pm 0.11$ \\
\hline L7 & $0.041 \pm 0.011$ & $<0.01$ & $11.67 \pm 0.626$ & $16.17 \pm 1.38$ \\
\hline F7 & $0.130 \pm 0.0156$ & $<0.01$ & $2.75 \pm 0.168$ & $13.68 \pm 1.02$ \\
\hline L8 & $0.059 \pm 0.013$ & $<0.01$ & $14.51 \pm 0.389$ & $21.83 \pm 2.00$ \\
\hline F8 & $0.117 \pm 0.021$ & $<0.01$ & $2.37 \pm 0.187$ & $<0.29$ \\
\hline $\mathrm{L}$ & $0.0843 \pm 0.104 \mathrm{a}$ & $0.282 \pm 0.158^{\mathrm{bB}}$ & $19.10 \pm 17.25 \mathrm{a}$ & $6.36 \pm 8.42^{\mathrm{aA}}$ \\
\hline $\mathrm{F}$ & $0.205 \pm 0.250 \mathrm{a}$ & $0.414 \pm 0.375^{\mathrm{aB}}$ & $3.52 \pm 2.91 \mathrm{~b}$ & $10.8 \pm 19.2^{\mathrm{aA}}$ \\
\hline
\end{tabular}

SD standard deviation. Values expressed as < (less than) denoted values lower than the quantification limit. Uppercase letters A, B denote statistical different content between polymers within each tissue type, whereas lowercase letters a, b denote statistical difference of liver and fat tissue based on the content of PC and PET

Highly non-significant correlations between tissuefree PTA and its polymer PET, and between tissue-free BPA and its polymer PC suggest that a big portion of free PTA and free BPA found inside the animal came from other sources than microplastics, such as plasticisers and previously decomposed plastics.
Harmful effects of plasticisers on laboratory animals have been demonstrated (Bang et al. 2011). One group of researchers hypothesises that plasticisers function as endocrine disruptors (Krishnan et al. 1993) and thus may have population-level effects on seabirds (van Franeker \& SNS Fulmar Study Group 2011).
Fig. 9 PC in liver and fat tissues per each turtle that is indicated by its biometric CCL

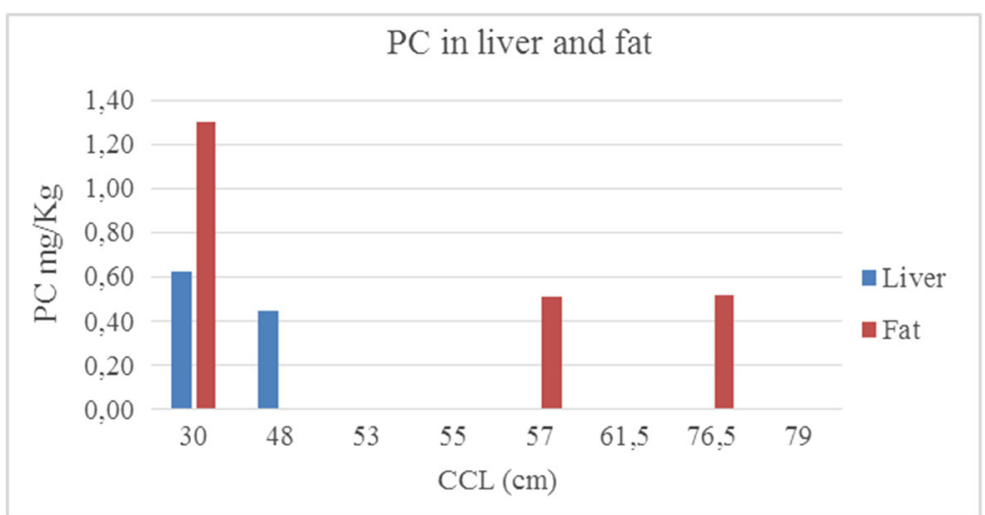


Fig. 10 PET in liver and fat tissues per each turtle that is indicated by its biometric CCL

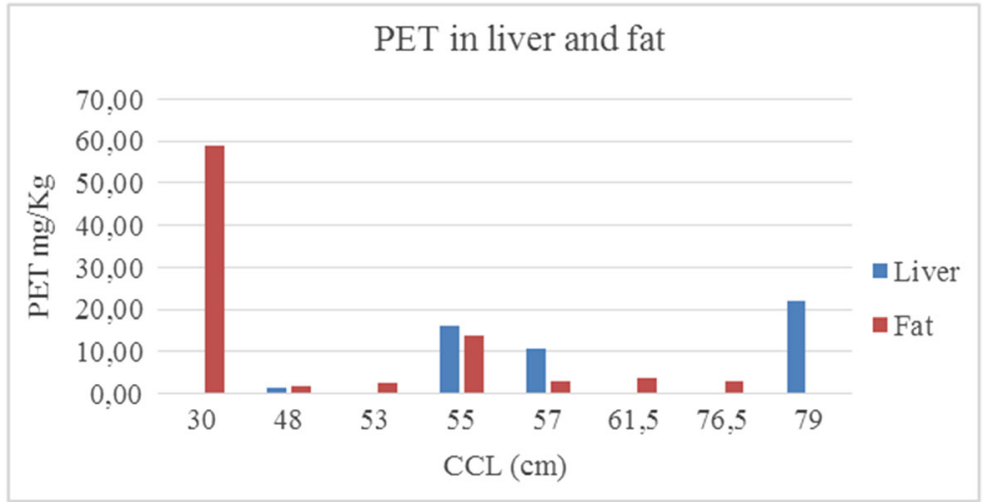

\section{Conclusion}

The potential of MPs chemicals for the contamination of soil, air and water is high (Hahladakis et al. 2018; Savoca et al. 2018; Campanale et al. 2020). Limits on the PTA migration from plastic of food have already been established in the European legislation for the protection of consumers as well as the BPA is permitted for use in food contact materials (FCMs) in the EU under Regulation 10/2011/EU, relating to plastic materials and articles intended for contact with foodstuffs having a specific migration limit. In general, few studies have been conducted investigating MPs and MPsassociated chemical additives, marine wild-population level presence and effects, tissue level distribution as well as the environmentally relevant concentrations (Flint et al. 2012; Fossi et al. 2012; Savoca et al. 2018).

Feeding preference may also affect the probability of debris ingestion by turtles. Carnivorous species (e.g. loggerhead and Kemp's ridley turtles) appear less susceptible to debris ingestion than herbivores (green), gelatinovores (leatherback) and omnivores (hawksbill), or perhaps they are less likely to retain the ingested debris (Schuyler et al. 2013).

Even small amounts of ingested debris can result in gut obstruction and mortality (Bjorndal et al. 1994). Mortality is not the only risk associated with debris ingestion; loggerheads are also able to eliminate plastic items through defecation, thus demonstrating a certain degree of tolerance as shown in previous studies (Tomas et al. 2002; Hoarau et al. 2014; Fukuoka et al. 2016). Then sub-lethal effect is generally suggested as the main impact on animal health (Nelms et al. 2015; Nicolau et al. 2016; Matiddi et al. 2017). Many studies on plastic ingestion by sea turtles have described the physical characteristics of ingested items, such as colour, size and type (foam, line, fragment, nurdle, sheet) (Jung et al. 2018).

Although MPs in the marine turtles were quantified by counting in marine turtle gut content, no detailed mass concentration of MPs in liver and fat tissues has been reported until now. Savoca et al. for the first time quantified the phthalates in four different tissues of sea
Fig. 11 Free BPA in liver and fat tissues per each turtle that is indicated by its biometric CCL

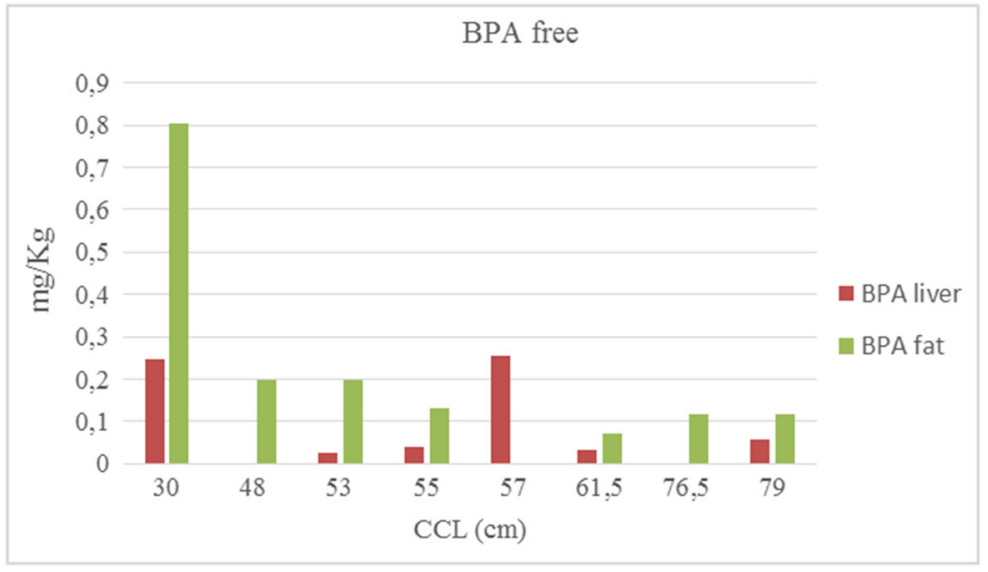


Fig. 12 Free PTA in liver and fat tissues per each turtle that is indicated by its biometric CCL

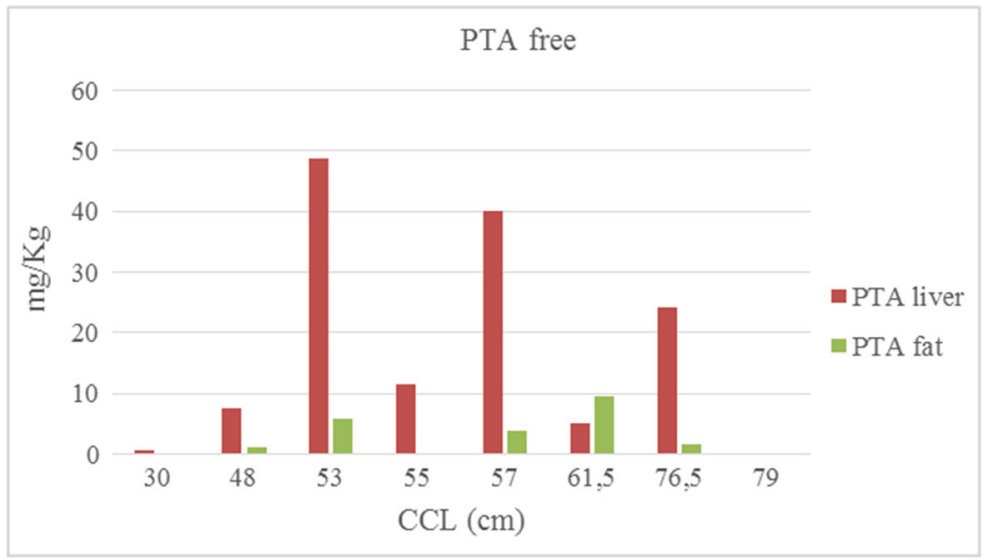

turtle from which they indirectly quantified the presence of microplastics.

Few studies reported the mass concentration of MPs in marine biota as indicator of environmental contaminants, including digestive residues of marine bivalves (Wang et al. 2019).

To the best of our knowledge, this is the first study reporting direct MP presence in the secondary tissue of sea turtle, liver and abdominal fat tissues. The study showed that the exposure of the polyethylene terephthalate was high in the Mediterranean Sea and confirmed sea turtle as suitable organism for the assessment of the spatial exposure of MPs polymers and plastic additives of concern (BPA and PTA).

Describing debris chemical characteristics helped us to understand its sources and factors that make it favourable for ingestion. This information, in turn, can help prioritise the most useful management options to mitigate plastic ingestion by sea turtles.

Despite some recent findings pointed out that at the bottom of the food pyramid, filter feeders, such as mussels can ingest and incorporate MPs in their tissues; further researches are needed to unveil the abundance, distribution and polymeric composition of plastic debris in marine organisms at different levels of ecological web in areas like the Adriatic Sea where multiple anthropogenic activities coexist.

Supplementary Information The online version contains supplementary material available at https://doi.org/10.1007/s11270021-04994-8.

Open Access This article is licensed under a Creative Commons Attribution 4.0 International License, which permits use, sharing, adaptation, distribution and reproduction in any medium or format, as long as you give appropriate credit to the original author(s) and the source, provide a link to the Creative Commons licence, and indicate if changes were made. The images or other third party material in this article are included in the article's Creative Commons licence, unless indicated otherwise in a credit line to the material. If material is not included in the article's Creative Commons licence and your intended use is not permitted by statutory regulation or exceeds the permitted use, you will need to obtain permission directly from the copyright holder. To view a copy of this licence, visit http://creativecommons.org/licenses/by/4.0/.

\section{References}

Avio, C. G., Pittura, L., d'Errico, G., Abel, S., Amorello, S., Marino, G., Gorbi, S., \& Regoli, F. (2020). Distribution and characterization of microplastic particles and textile microfibers in Adriatic food webs: general insights for biomonitoring strategies. Environmental Pollution, 258, 113766.

Bang, D. Y., Lee, I. K., \& Lee, B.-M. (2011). Toxicological characterization of phthalic acid. Toxicological Residue, 27(4), 191-203.

Bjorndal, K. A. (1997). Foraging ecology and nutrition of sea turtles. Biology of Sea Turtles, 199-231.

Browne, M. A., Dissanayake, A., Galloway, T. S., Lowe, D. M., \& Thompson, R. C. (2008). Ingested microscopic plastic traslocates to the circulatory system of the mussel, Mytilus edulis (L). Environmental Science Technology, 42, 50265031.

Campanale, C., Massarelli, C., Savino , I., Locaputo, and Uricchio, F.V. (2020) A detailed review study on potential effects of microplastics and additives of concern on human health. International Journal of Environmental Residue. Public Health, 17, 1212; doi:https://doi.org/10.3390 /ijerph17041212

Caron, A. G. M., Thomas, C. R., Berrya, K. L. E., Mottia, C. A., Arield, E., \& Brodie, J. E. (2018a). Ingestion of microplastic debris by green sea turtles (Cheloniamydas) in the Great Barrier Reef: validation of a sequential extraction protocol. Marine Pollution Bullettin, 127, 743-751. 
Caron, A. G. M., Thomas, C. R., Berry, K. L. E., Motti, C. A., Ariel, E., \& Brodie, J. E. (2018b). Validation of an optimised protocol for quantification of microplastics in heterogenous samples: a case study using green turtle chyme. Methods $X, 5$, 812-823.

Casale, P., Mazaris, A. D., \& Freggi, D. (2011). Estimation of age at maturity of loggerhead sea turtles Caretta caretta in the Mediterranean using length-frequency data. Endangered Species Researched, 13, 123-129.

Casini, S., Caliani, I., Giannetti, M., Marsili, L., Maltese, S., Coppola, D., Bianchi, N., Campani,T., Ancora, S., Caruso, C., Furii, G, Parga, M., D’Agostino, A., Fossi, M.C. (2018)First ecotoxicological assessment of Caretta caretta (Linnaeus, 1758) in Mediterranean Sea using an integrated non destructive protocol. Science of the Total Environment, $631,1221-1233$.

Coyle, R., Hardiman, G., \& O’ Driscoll, K. (2020). Microplastics in the marine environment: a review of their sources, distribution processes and uptake into ecosystems. Case Studies in Chemical and Environmental Engineering. https://doi. org/10.1016/j.cscee.2020.100010.

DCA 16/02/2018 n.12. (n.d.) Recepimento dell'Accordo tra il Governo, le Regioni e le Province Autonome di Trento e di Bolzano sullo schema di linee guida per il recupero, soccorso, affidamento e gestione delle tartarughe marine ai fini della riabilitazione e per la manipolazione a scopi scientifici (Rep Atti n. 83 CSR del 10 luglio 2014); Procedura Regionale per la Gestione delle segnalazioni di carcasse di tartarughe marine o di cetacei ritrovate sul litorale molisano, e del ritrovamento di animali marini vivi, feriti e/o in difficoltà.

Deudero, S., \& Alomar, C. (2015). Mediterranean marine biodiversity under threat: reviewing influence of marine litter on species. Marine Pollution Bulletin, 98, 58-68.

Di Renzo, L., Mascilongo, G., Di Giacinto, F., Zezza, D., Di Francesco, G., Olivieri, V., Berti, M., Petrini, A., \& Ferri, N. (2020). Extraction protocol optimization for detection of microplastics in digestive system contents of loggerhead turtle (Caretta caretta). In Proceedings of the 2 nd International Conference on Microplastic Pollution in the Mediterranean Sea, Springer Nature Switzerland AG 2020 M. Cocca et al. (Eds.): ICMPMS 2019, SPWA (pp. 205-211).

Digka, N., Bray, L., Tsangaris, C., Andreanidou, K. Kasimati, E., Kofidou, E., Komnenou, A., \& Kaberi, H. (2020). Evidence of ingested plastics in stranded loggerhead sea turtles along the Greek coastline, East Mediterranean Sea. Enviromental Pollution, 263, A.

Flint, M., Patterson, K. J. C., Limpus, C. J., Work, T. M., Blair, D., \& Mills, P. C. (2009). Postmortem diagnostic investigation of disease in free-ranging marine turtle populations: a review of common pathologic findings and protocols. Journal of Veterinary Diagnostic Investigation, 21, 733-759.

Fossi, M. C., Panti, C., Guerranti, C., Coppola, D., Giannetti, M., Marsili, L., \& Minutoli, R. (2012). Are beleen whales exposed to the threat of microplastic? A case study of the Mediterranea fin whale (Balenopterephysalus). Marine Pollution Bulletin, 64, 2374-2379.

Fossi, M. C., Ped, A. C., Compa, M., Tsangaris, C., Alomar, C., Claro, F., Ioakeimidis, C., Galgani, F., Hema, T., Deudero, S., Romeo, T., Battaglia, P., Andaloro, F., Caliani, I., Casini, S., Panti, C., \& Baini, M. (2018). Bioindicators for monitoring marine litter ingestion and its impacts on Mediterranean biodiversity. Environmental Pollution, 237, 1023-1040.

Frick, M., Williams, K., Bolten, A., Bjorndal, K., \& Martins, H. (2009). Foraging ecology ofoceanic-stage loggerhead turtles Caretta caretta. Endangered Species Researched, 9, 91-97.

Fukuoka, T., Yamane, M., Kinoshita, C., Narazaki, T., Marshall, G. J., Abernathy, K. J., Miyazaki, N., \& Sato, K. (2016). The feeding habit of sea turtles influences their reaction to artificial marine debris. Scientific Reports, 6, 28015. https://doi. org/10.1038/srep28015.

GESAMP (2015) Source, fate and effects of microplastic in the marine environment: a global assessment, 97 Rep Study $\mathrm{N}_{\mathrm{o}}$ 90.

GESAMP, 2019. Guidelines for the monitoring and assessment of plastic litter and microplastics in the ocean. Rep. Stud. GESAMP No.. In: Kershaw, P.J., Turra, A., Galgani, F. (Eds.), IMO/FAO/UNESO-IOC/UNIDO/WMO/IAEA/UN/ UNEP/UNDP/ISA Joint Group of Experts on the Scientific Aspects of Marine Environmental Protection), vol. 99, pp. 812.

Gomiero, A., Srafella, P., \& Fabi, G. (2018). From macroplastic to microplastic litter: occurrence, composition, source identification, interaction with aquatic organisms and fate in the marine environment: experiences from the Adriatic Sea. IntechOpen, 1-21.

Hahladakis, N. J., Costas, A. V., Weber, R., Iacovidou, E., \& Purnell, P. (2018). An overview of chemical additives present in plastics: migration, release, fate and environmental impact during their use, disposal and recycling. Journal of Hazardous Materials, 344, 179-199.

Hoarau, L., Ainley, L., Jean, C., \& Ciccione, S. (2014). Ingestion and defecation of marine debris by loggerhead sea turtles, Caretta caretta, fromby-catches in the South-West Indian Ocean. Marine Pollution Bulletin, 84, 90-96.

Hoshi, A. and Kuretani, K. (1967). Metabolism of terephthalicacid. Absorption of terephthalic acid from the gastrointestinal tract and detection of its metabolites. Chemical and Pharmaceutical Bulletin, 15, 1979-1984.

Hoshi, A., \& Kuretani, K. (1968). Distribution of terephthalic acid in tissues. Chemical and Pharmaceutical Bulletin, 16, 131135.

Hong, H. S., Shim, W. J., \& Jang, M. (2018). Chemicals associated with marine plastic Debisan microplastic: analyses and contaminant levels. Microplastic contamination in Aquatic Environmental, c, 9, 271-315.

IUCN (2015). Red list of threatened species. Version 2020.1.

Jung, M. R., Horgen, F. D., Orski, S. V., Rodriguez C., V., Beers, K. L., FT Balazs, G. H., Lynch, J. M. (2018). Validation of ATR-IR to identify polymers of plastic marine debris, including those ingested by marine organisms. Marine Pollution Bulletin, 127, 716. https://doi.org/10.1016/j. marpolbul.2017.12.061.

Krishnan, A. V., Stathis, P., Permuth, S. F., Tokes, L., \& Feldman, D. (1993). Bisphenol-A: an estrogenic substance is released from polycarbonate flasks during autoclaving. Endocrinology, 132, 2279-2279.

Lazar, B., \& Gracan, R. (2011). Ingestion of marine debris by loggerhead sea turtle, Caretta caretta in the Adriatic Sea. Marine Pollution Bulletin, 62, 43-47. 
Lenz, R., Enders, K., Stendom, C. S., Mackenzi, D. M. A., \& Nielsen, T. G. (2015). A critical assessment of visual identification of marine microplastic using Raman spectroscopy for analysis improvement. Marine Pollution Bullettin, 100, 82-91.

Margaritoulis, D., Argano, R., Baran, I., Bentivegna, F., Bradai, M. N., Camiñas, J. A., Casale, P., De Metrio, G., Demetropoulos, A., Gerosa, G., Godley, B. J., Haddoud, D. A., Houghton, J., Laurent, L., \& Lazar, B. (2003). Loggerhead turtles in the Mediterranean: present knowledge and conservation perspectives. In A. B. Bolte \& B. Witherington (Eds.), Biology of conservation of Loggerhead Sea turtles (pp. 175-198). Washington DC: Smlthson. Int. Press.

Matiddi, M., deLucia, G.A., Silvestri, C., Darmon, G., Tomás, J., Pham, K.C., Camedda, A.,Vandeperre, F., Claro, F., Kaska, J., Kaberi, H., Revuelta, O., Piermarini, R., Daffina, R., Pisapia, M., Genta, D., Sözbilen, D., Bradai, M.N., Rodríguez, J., Gambaiani, D., Tsangaris,C., Chaieb, O., Moussier, J., Loza, A.L., Miaud C. (2019). Data collection on marine litter ingestion in sea turtles and thresholds for good environmental status. JoVE.https://www.jove. com/video/59466/data-collection-on-marine-litter-ingestionsea-turtles-thresholds-for.

Matiddi, M., Hochsheid, S., Baini, M., Cocumelli, C., Serena, F., Travaglini, A., Marra, S., Campani, T., Scholl, F., Mancusi, C., Amato, E., Brigugli, P., Maffucci, F., Fossi, M. C., Bentivegna, F., \& Andrea de Lucia, G. (2017). Loggerhead sea turtles (Caretta caretta): a target species for monitoring litter ingested by marine organisms in the Mediterranean Sea. Environtal Pollution, 230, 199-209.

Matiddi, M., van Franeker, J.A., Sammarini, V., Travaglini, A., Alcaro, L. (2011) Monitoring litter by sea turtles: an experimental protocol in the Mediterranean. Ecosystem. 4th Mediterranean Conference on Marine Turtles, Naples, Italy, 2011.

Miller, M. E., Kroon, F. J., \& Motti, C. A. (2017). Recovering microplastics from marine samples: a review of current practices. Marine Pollution Bullettin, 123, 6-18.

MSFD-TSGML(2013). Guidance on monitoring of marine litter in European Seas. A guidance document within the common implementation strategy for the marine strategy framework directive. EUR-26113 EN. JRC Scientific and Policy Reports J R C 83985 . h t t p : / / m c c.j r c. e c . e u r o p a . eu/documents/201702074014.pdf.

Nelms, S. E., Duncan, E. M., Broderick, A. C., Galloway, T. S., Godfrey, M. H., Hamann, M., Lindeque, P. K., \& Brendan, G. J. (2015). Plastic and marine turtles: a review and call for research. ICES Journal of Marine Science. https://doi. org/10.1093/icesjms/fsv165.

Nicolau, L., Marçalo, A., Ferreira, M., Sé, S., Vingada, J., \& Eira, C. (2016). Ingestion of marine litter by loggerhead sea turtles, Caretta caretta, in Portuguese continental waters. Marine Pollution Bulletin, 103, 179-185.

NOAA Techinal memorandum NOS-Or \& R-30 (2009).

Palatinus, A., Kovač Viršek, M., Robič, U., Grego, M., Bajt, O., Šiljić, J., Suaria, G., Liubartseva, S., Coppini, G., \& Peterlin, M. (2019). Marine litter in the Croatian part of the middle Adriatic Sea: simultaneous assessment of floating and seabed macro and micro litter abundance and composition. Marine Pollution Bulletin, 139, 427-439.

Plotkin, P., Amos, A.F., (1990). Effects of anthropogenic debris on sea turtles in Northwestern gulf of Mexico. In: Shomura R.S., Godfrey M.L. (Eds.) Proceedings of the Second International Conference on Marine Debris. NOAA Technical Memorandum NMSF-SEFC-154,Honolulu, Hawai, pp.736-743.

Poppi, L., \& Di Bello, A. (2015). Manuale di gestione delle tartarughe marine. Netcet .

Savoca, D., Arculeo, M., Barreca, S., Buscemia, S., Caracappa, S., Gentile, A., Persichetti, M. F., \& Pace, A. (2018). Chasing phthalates in tissues of marine turtles from the Mediterranean sea. Marine Pollution Bulletin, 127, 165-169.

Schuyler, Q., Hardesty, D. B., Wilcox, C., \& Townsend, K. (2013). Global analysis of anthropogenic debris ingestion by sea turtles. Conservation Biology, 28, 129-139.

Suaria, G., \& Aliani, S. (2014). Floating debris in the Mediterranean Sea. Marine Pollution Bulletin, 86, 494-504.

Thomas, J., Guitart, R., Mateo, R., \& Raga, J. A. (2002). Marine debris ingestion in loggerhead sea turtles, Caretta caretta, from the Western Mediterranean. Marine Pollution Bulletin, 44, 211-216.

UNEP. (2009). Marine Litter: A Global Challenge. Nairobi: UNEP.

UNEP. (2005). Marine litter:aAn analytical overview. Nairobi: UNEP.

Van der Hal, N., \& Ariel, A. (2017). Exceptionally high abundances of microplastics in the oligotrophic Israeli Mediterranean coastal waters. Marine Pollution Bulletin, 151-155.

van Franeker, J. A., \& SNS Fulmar Study Group. (2011). Chemicals in marine plastics and potential risks for a seabird like the Northern Fulmar (Fulmarus glacialis). In B. Carswell, K. McElwee, \& S. Morison (Eds.), Fifth international marine debris conference (pp. 415-418). Honolulu: National Oceanic and Atmospheric Adminstration.

Wang, Q., Chen, G., Chen, P., Cui, S., Yi, S., \& Zhu, L. (2017). Bioaccumulation and biomagnification of emerging bisphenol analogues in aquatic organisms from Taihu Lake, China. Science of the Total Environmental, 598, 814-820.

Wang, W., Gao, H., Jin, S., Li, R., Na, G.(2019) The ecotoxicological effects of microplastics o acquatic food web, from primary producer to human: a review. Ecotoxicology and Environmental Safety, 173, 110-117. Woodall, L,C, Gwinnett, C, Packer, M, Thompson, R,C, Robinson, L,F, Paterson, G,L,J. (2015) Using a forensic science approach to minimize environmental contamination and to identify microfibres in marine sediments. Marine Pollution Bulletin, 95, 40-46.

Zhang, J., Wang, L., Halden, R. U., \& Kannan, K. (2019). Polyethylene terephthalate and polycarbonate microplastics in sewage sludge collected from the United States. Environmental Science \& Technology Letters, 6, 650-655.

Publisher's Note Springer Nature remains neutral with regard to jurisdictional claims in published maps and institutional affiliations. 